\title{
Psoriasis in children. Diagnostic and therapeutic recommendations of the Polish Dermatological Society. Part I
}

\author{
Łuszczyca u dzieci. Rekomendacje diagnostyczno-terapeutyczne \\ Polskiego Towarzystwa Dermatologicznego. Część I
}

Joanna Narbutt' ${ }^{1}$ Adam Reich², Zygmunt Adamski ${ }^{3}$, Grażyna Chodorowska ${ }^{4}$, Andrzej Kaszuba', Dorota Krasowska ${ }^{4}$, Aleksandra Lesiak', Joanna Maj ${ }^{5}$, Agnieszka J. Osmola-Mańkowska ${ }^{5}$, Agnieszka B. Owczarczyk-Saczonek ${ }^{6}$, Witold Owczarek ${ }^{7}$, Waldemar J. Placek ${ }^{6}$, Lidia Rudnicka ${ }^{8}$, Jacek Szepietowski ${ }^{5}$

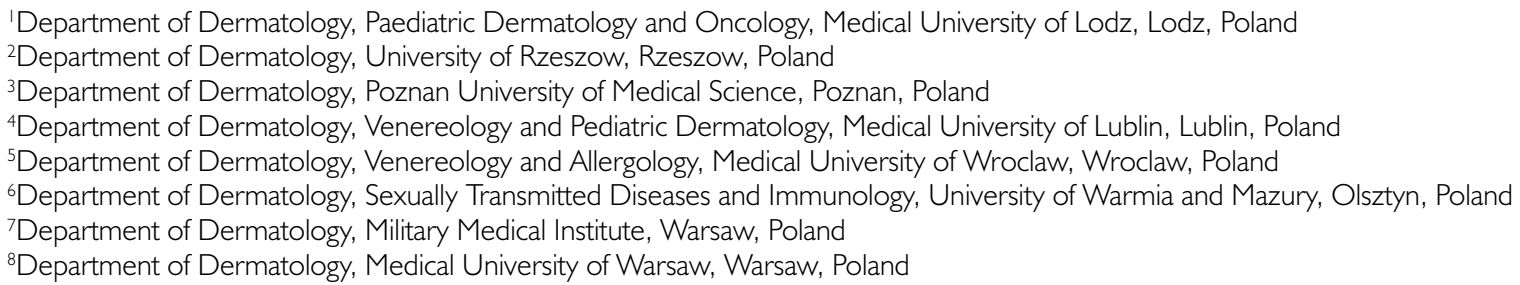

'Klinika Dermatologii, Dermatologii Dziecięcej i Onkologicznej, Uniwersytet Medyczny, Łódź, Polska

2Zakład i Klinika Dermatologii, Uniwersytet Rzeszowski, Rzeszów, Polska

${ }^{3}$ Katedra i Klinika Dermatologii, Uniwersytet Medyczny, Poznań, Polska

${ }^{4}$ Katedra i Klinika Dermatologii, Wenerologii i Dermatologii Dziecięcej, Uniwersytet Medyczny, Lublin, Polska

${ }^{5}$ Katedra i Klinika Dermatologii, Wenerologii i Alergologii, Uniwersytet Medyczny, Wrocław, Polska

${ }^{6}$ Katedra i Klinika Dermatologii, Chorób Przenoszonych Drogą Płciową i Immunologii, Uniwersytet Warmińsko-Mazurski, Olsztyn, Polska

${ }^{7}$ Klinika Dermatologii, Wojskowy Instytut Medyczny, Warszawa, Polska

${ }^{8}$ Katedra i Klinika Dermatologii, Warszawski Uniwersytet Medyczny, Warszawa, Polska

Dermatol Rev/Przegl Dermatol 2021, 108, 239-257

DOI: https://doi.org//0.51|4/dr.2021.1 10913

\author{
CORRESPONDING AUTHOR/ \\ ADRES DO KORESPONDENCJI: \\ prof. dr hab. n. med. \\ Joanna Narbutt \\ Uniwersytet Medyczny \\ Łódź, Polska \\ tel.: +48603756 804 \\ e-mail: joanna.narbutt@umed. \\ lodz.pl
}

\begin{abstract}
Introduction: Psoriasis is a chronic inflammatory disease that affects approximately $1-3 \%$ of the general population. In children, it occurs less frequently, most often develops in adolescence. Due to the more and more common forms of moderate and severe psoriasis in the pediatric population, it is necessary to present its nature, clinical presentation and comorbidity, as well as to standardize the therapeutic procedure. In the last dozen or so years, tremendous progress has been made in the pathogenesis of psoriasis, which has resulted in introduction of new therapeutic aims and methods of treatment. A fuller understanding of the nature of the disease, its coexistence with other diseases and a negative impact on the quality of life require a multidisciplinary approach and implementation of appropriate treatment, depending on the severity of the disease.

Objective: The purpose of recommendations of the Polish Dermatological Society is to present the literature current data on the use of local and systemic treatment, including biological therapies in psoriasis in the pediatric population. Coexisting diseases are also presented, as well as the impact of the dermatosis on the quality of life of children.
\end{abstract}

Material and methods: Recommendations were developed by a group of experts of the Polish Dermatological Society, taking into account their clinical experience, as well as the latest reports in Polish and world 
literature. Principles of treating psoriasis, useful in everyday dermatological practice, are taken into account.

Results and conclusions: Recommendations discuss principles of local treatment, classic systemic treatment and biological therapies. Treatment of psoriasis in children and adolescents poses a challenge for a dermatologist. Drugs approved for the treatment of this severe disease in the pediatric population have been introduced recently. The therapeutic procedure must be individualized. Systemic treatment should be considered for all psoriasis affecting more than $10 \%$ of the body.

Key words: psoriasis, children, treatment, recommendations.

\section{STRESZCZENIE}

Wprowadzenie: Łuszczyca jest przewlekłą chorobą zapalną dotyczącą około 1-3\% populacji ogólnej. U dzieci występuje rzadziej, najczęściej rozwija się w wieku nastoletnim. Ze względu na coraz częściej występujące postaci łuszczycy o umiarkowanym i ciężkim w przebiegu $\mathrm{w}$ populacji pediatrycznej, konieczne jest przedstawienie jej charakteru, obrazu klinicznego oraz współchorobowości, a także ujednolicenie postępowania terapeutycznego. W ostatnich kilkunastu latach dokonał się ogromny postęp w zakresie patogenezy łuszczycy, co poskutkowało wprowadzeniem nowych celów terapeutycznych oraz metod leczenia tej choroby. Pełniejsze poznanie istoty schorzenia, jej współistnienie $\mathrm{z}$ innymi jednostkami chorobowymi oraz negatywny wpływ na jakość życia wymagają wielospecjalistycznego podejścia i wdrażania odpowiedniego leczenia, w zależności od nasilenia choroby.

Cel pracy: Celem rekomendacji Polskiego Towarzystwa Dermatologicznego jest przedstawienie aktualnych danych z piśmiennictwa dotyczących stosowania leczenia miejscowego oraz ogólnego z uwzględnieniem terapii biologicznych $\mathrm{w}$ łuszczycy $\mathrm{w}$ populacji pediatrycznej. Przedstawione są również choroby współistniejące, a także wpływ dermatozy na jakość życia dzieci.

Materiał i metody: Rekomendacje zostały opracowane w grupie ekspertów Polskiego Towarzystwa Dermatologicznego z uwzględnieniem ich doświadczenia klinicznego, a także najnowszych doniesień z piśmiennictwa polskiego i światowego. Uwzględniono zasady leczenia łuszczycy przydatne w codziennej praktyce dermatologicznej.

Wyniki i wnioski: W rekomendacjach omówiono zasady leczenia miejscowego, ogólnego klasycznego oraz terapii biologicznych. Leczenie łuszczycy u dzieci i młodzieży stanowi wyzwanie dla lekarza dermatologa. Dopiero w ostatnich latach wprowadzono leki posiadające rejestrację $\mathrm{w}$ terapii tej ciężkiej choroby $\mathrm{u}$ dzieci. Postępowanie terapeutyczne musi być zindywidualizowane. W każdym przypadku łuszczycy zajmującej powierzchnię powyżej 10\% ciała należy rozważyć leczenie ogólne.

Słowa kluczowe: łuszczyca, dzieci, leczenie, rekomendacje.

\section{INTRODUCTION}

Psoriasis is a chronic, inflammatory, immunemediated disease. It affects about $1-3 \%$ of the adult population, and it is believed that about $1 / 3$ of cases begin in childhood, most often after adolescence [1-3]. It is estimated that the incidence of psoriasis in

\section{WPROWADZENIE}

Łuszczyca jest przewlekłą chorobą zapalną o podłożu immunologicznym. Dotyczy około 1-3\% dorosłych, przy czym uznaje się, że około $1 / 3$ przypadków zaczyna się w dzieciństwie, najczęściej po okresie dojrzewania [1-3]. Szacuje się, że zapadalność 
children is $0.7-2.1 \%$ [2]. Prevalence of this disease in the pediatric population increases linearly with age [4]. Due to the recurrent course, as well as its systemic nature and coexistence of other diseases, psoriasis significantly affects the quality of life of patients and their general health. For this reason, the diagnostic and therapeutic approach in children with psoriasis must be broad, also taking into account psychological aspects. The therapeutic process should take into account not only the patient himself/herself, but also his/her parents and guardians, as the disease affects all family members.

A tremendous progress has been made in the pathogenesis of psoriasis in the last dozen or so years, which has resulted in the introduction of new therapeutic aims and methods of treatment. A fuller understanding of the nature of the disease, its coexistence with other diseases and a negative impact on the quality of life require a multidisciplinary approach and implementation of appropriate treatment, depending on the severity of the disease.

\section{CLINICAL PRESENTATION AND DIAGNOSIS OF PSORIASIS}

The most common clinical form of psoriasis in children is plaque psoriasis (about $70 \%$ of patients). In most cases, the diagnosis of psoriasis is based on the morphology and typical localization of skin lesions (scalp, extension surfaces of elbows and knees, the sacro-lumbar region, nails), but the location of plaque psoriasis in children may be slightly different. In adults, more often than in children, lesions are located on the skin of the face, eyelids, auricles, and also in intertriginous areas (navel, armpits, groin, genitals) $[2,5]$. In addition, smaller and less infiltrated psoriatic plaque is also observed in children, sometimes without the characteristic scales. In the youngest children, due to a different structure of the epidermis and greater hydration of the skin, lesions may be oozing and appear as erythematous-edema foci, with frequent localization in the anogenital area (psoriatic diaper dermatitis). Therefore, in doubtful cases, it is advisable to perform a histopathological examination of a skin specimen. However, it should be remembered that the histological presentation may depend not only on the type of psoriasis, but also on the previous treatment. Therefore, before making a decision to take a skin biopsy for histological examination, it is necessary to discontinue local treatment, especially anti-inflammatory one [6]. About $1 / 3$ of children with plaque psoriasis develop nail lesions with an oily spot, pinpoint dimples (thimble symptom) or onycholysis, subungual hyperkeratosis and onychodystrophy. Presence of psoriasis in this local- na łuszczycę u dzieci wynosi 0,7-2,1\% [2]. Częstość występowania tej jednostki chorobowej w populacji pediatrycznej wzrasta liniowo z wiekiem [4]. Ze względu na nawrotowy przebieg, a także jej charakter ogólnoustrojowy i współwystępowanie innych schorzeń, łuszczyca istotnie wpływa na jakość życia chorych oraz ich ogólny stan zdrowia. Z tego względu podejście diagnostyczno-terapeutyczne u dzieci z łuszczycą musi być szerokie, uwzględniające również aspekty psychologiczne. W procesie leczniczym należy uwzględnić nie tylko pacjenta, lecz także jego rodziców i opiekunów, gdyż choroba obciąża wszystkich członków rodziny.

W ostatnich kilkunastu latach dokonał się ogromny postęp w zakresie patogenezy łuszczycy, co poskutkowało wprowadzeniem nowych celów terapeutycznych oraz metod leczenia tej choroby. Pełniejsze poznanie istoty choroby, jej współistnienie $\mathrm{z}$ innymi jednostkami chorobowymi oraz negatywny wpływ na jakość życia wymagają wielospecjalistycznego podejścia i wdrażania odpowiedniego leczenia, w zależności od nasilenia choroby.

\section{OBRAZ KLINICZNY I ROZPOZNANIE ŁUSZCZYCY}

Najczęstszą odmianą kliniczną łuszczycy u dzieci jest łuszczyca plackowata (ok. 70\% chorych). Rozpoznanie łuszczycy w większości przypadków ustala się na podstawie morfologii oraz typowej lokalizacji zmian skórnych (skóra owłosiona głowy, wyprostne powierzchnie łokci i kolan, okolica krzyżowo-lędźwiowa, paznokcie). U dzieci umiejscowienie łuszczycy plackowatej może być jednak nieco odmienne, gdyż częściej niż u dorosłych zmiany pojawiają się na skórze twarzy, powiek, małżowin usznych, a także w okolicach wyprzeniowych (pępek, pachy, pachwiny, narządy płciowe) $[2,5]$. Ponadto u dzieci obserwuje się też mniejsze i mniej nacieczone tarczki łuszczycowe, niekiedy bez charakterystycznej łuski. U najmłodszych dzieci, ze względu na odmienności budowy naskórka oraz większe uwodnienie skóry, zmiany mogą być sączące i występować w postaci ognisk rumieniowo-obrzękowych, z częstą lokalizacją w okolicach anogenitalnych (łuszczycowe pieluszkowe zapalenie skóry). W przypadkach wątpliwych wskazane jest wykonanie badania histopatologicznego z wycinka skóry. Należy jednak pamiętać, że obraz histologiczny może zależeć nie tylko od typu łuszczycy, lecz także wcześniej stosowanego leczenia. Dlatego przed podjęciem decyzji o pobraniu wycinka skóry do badania histologicznego konieczne jest odstawienie leczenia miejscowego, szczególnie przeciwzapalnego [6]. U około 1/3 dzieci z łuszczycą plackowatą występują zmiany paznokciowe z obecnością plamy olejowej, punkcikowatych wgłębień (objaw naparstka) bądź onycholizą, hiperkeratozą pod- 
ization is considered a risk factor for the development of psoriatic arthritis.

The second most common clinical variant is psoriasis guttata. It affects $15-30 \%$ of children [2]. It is characterized by the sudden spreading of monomorphic papules $<1 \mathrm{~cm}$ in diameter, mainly on the trunk. Usually, the disease is preceded (1-3 weeks) by an acute infection of the upper respiratory tract (most often tonsillitis) or streptococcal proctitis, caused by $\beta$-hemolytic streptococci from groups A, C and G. Less often, skin lesions may be preceded by a viral infection [5]. This form of psoriasis is self-limiting, usually remission is achieved after 3-4 months of treatment.

Pustular psoriasis occurs rarely in children (1$5.4 \%)$, and the annular pattern of lesions is more common in the generalized form. Generalized skin changes may be accompanied by systemic symptoms such as fever, weakness, fatigue or joint pain. In this case, hospitalization and general treatment are required. The form of pustular psoriasis, confined to the hands and feet, is extremely rare in children $[4,5]$.

\section{INTENSIFICATION OF THE PATHOLOGY}

The assessment of the severity of the disease in children is an essential diagnostic element that allows for the selection of an optimal treatment method. As a rule, the assessment is made using three scales, analogous to adult patients. The severity of skin lesions is determined using the Psoriasis Area and Severity Index scale (PASI), and the area of skin affected by lesions is assessed using body surface area (BSA). To determine the quality of life in children, the Children's Dermatology Life Quality Index (CDLQI) is used. It is a version of the DLQI questionnaire adapted to children aged 4-16. It consists of 10 questions, specific to skin diseases, designed to assess the impact of skin disease on the patient's quality of life during the last 7 days. Each question is answered on a scale of 0 (no impact) to 3 (very high impact). The CDLQI value is the sum of the points obtained from the answers to each question in the questionnaire (0-30). The questionnaire assesses 6 domains: symptoms and feelings related to the disease, daily activities, free time, work and school, personal relationships and treatment. Younger children complete the questionnaire supported by their parents/ guardians, older children do it on their own [7, 8]. For children aged 4-11 years old there are also illustrated versions of the scale.

The assessment of PASI, BSA and CDLQI indicators is related to the choice of the therapy. Mild forms of psoriasis require local therapy, while moderate and severe disease requires supplementing the treat- paznokciową i onychodystrofią. Występowanie łuszczycy w tej lokalizacji uznaje się za czynnik ryzyka rozwoju łuszczycowego zapalenia stawów.

Drugą co do częstości występowania odmianą kliniczną jest postać drobnogrudkowa (tzw. wysiewna). Dotyczy ona 15-30\% dzieci [2]. Charakteryzuje się nagłym wysiewem monomorficznych grudek o średnicy $<1 \mathrm{~cm}$, przede wszystkim na tułowiu. Zazwyczaj choroba jest poprzedzona (1-3 tygodnie) ostrą infekcją górnych dróg oddechowych (najczęściej zapalenie migdałów) lub paciorkowcowym zapaleniem odbytu, wywołanymi paciorkowcami $\beta$-hemolitycznymi z grupy A, C i G. Rzadziej zmiany skórne mogą być poprzedzone infekcją wirusową [5]. Ta postać łuszczycy jest samoograniczająca się, zwykle po 3-4-miesięcznym okresie leczenia uzyskuje się remisję.

Łuszczyca krostkowa u dzieci występuje rzadko (1-5,4\%), a w postaci uogólnionej częściej obserwuje się obrączkowaty układ zmian. Uogólnionym zmianom skórnym mogą towarzyszyć objawy ogólne, takie jak gorączka, osłabienie, zmęczenie czy bóle stawowe. W takim przypadku wymagana jest hospitalizacja i włączenie leczenia ogólnego. Niezwykle rzadko u dzieci stwierdza się postać łuszczycy krostkowej ograniczoną do rąk i stóp $[4,5]$.

\section{NASILENIE PROCESU CHOROBOWEGO}

Ocena nasilenia procesu chorobowego $u$ dzieci jest niezbędnym elementem diagnostycznym, pozwalającym na wybór optymalnej metody leczenia. Zazwyczaj ocenę przeprowadza się z zastosowaniem trzech skal, podobnie jak u pacjentów dorosłych: nasilenia zmian skórnych w skali PASI (Psoriasis Area and Severity Index), powierzchni zajętej skóry (body surface area - BSA) oraz wpływu choroby na jakość życia dziecka (Children's Dermatology Life Quality Index - CDLQI). Jest to wersja kwestionariusza jakości życia DLQI dostosowana do dzieci w wieku 4-16 lat. Składa się z 10 pytań, specyficznych dla chorób skóry, stworzonych w celu oceny wpływu schorzenia skóry na jakość życia pacjenta w 7 ostatnich dniach. Odpowiedź na każde pytanie podawana jest w skali 0 (brak wpływu) do 3 (bardzo duży wpływ). Wartość wskaźnika CDLQI jest sumą punktów uzyskanych z odpowiedzi na każde pytanie kwestionariusza (0-30). Kwestionariusz ocenia 6 domen: objawy i odczucia związane z chorobą, codzienną aktywność, czas wolny, pracę i szkołę, związki osobiste oraz leczenie. Młodsze dzieci wypełniają kwestionariusz wspólnie z rodzicami lub opiekunami, starsze - samodzielnie [7,8]. Dla dzieci w wieku 4-11 lat istnieją też wersje rysunkowe skali.

Ocena wskaźników PASI, BSA i CDLQI wiąże się $\mathrm{z}$ wyborem procesu terapeutycznego. Łagodne postaci łuszczycy wymagają terapii miejscowej, natomiast umiarkowany i ciężki przebieg choroby związany jest 
ment with phototherapy or systemic, conventional or biological medications.

Similarly to adult patients, mild psoriasis is defined when skin lesions occupy less than $10 \%$ of the total skin surface (BSA $<10 \%$ ), the PASI scale does not exceed 10 points, and the negative impact of the disease on quality of life according to the CDLQI index is less than 10 points. Exceeding any value above 10 allows for the diagnosis of moderate to severe psoriasis. However, many studies defining the severity of psoriasis in children indicate that determination of the mild, moderate or severe form can already be made on the basis of the BSA calculation. According to Menter et al. [9], it is considered that in children the same classification of psoriasis can be used based on BSA as in adult patients, where skin involvement of psoriatic lesions of BSA $<3 \%$ means mild psoriasis, BSA $3-10 \%$ - moderate psoriasis, and BSA > 10\% - severe psoriasis. Determination of the area of the skin affected by psoriatic lesions is determined by the method of nines, taking into account the region of the body depending on the age. In specific forms of the disease, when the above-mentioned indicators (BSA, PASI) score less than 10 points, but psoriatic lesions affect special locations (e.g. scalp, genital area, hands, feet), or cause subjective symptoms (pruritus, skin pain) and are associated with restriction of daily activities or fulfillment of compulsory schooling, which impairs the quality of life, they can be considered as consistent with the severe course of psoriasis.

\section{COEXISTING DISEASES}

Psoriasis is a systemic disease. In adult patients, numerous comorbidities have been confirmed, such as psoriatic arthritis (PsA), metabolic syndrome, cardiovascular disease, dyslipidemia, obesity, and depression. Many of these comorbidities may also be associated with pediatric patients, although data on this is scarce and appropriate research is in progress. Current clinical observations and knowledge from the published research results require a broader look at a child with psoriasis and taking appropriate diagnostic and therapeutic course to correct the impact of psoriasis on the quality of life and general health at an early stage.

\section{Psoriatic arthritis}

Juvenile idiopathic arthritis (JIA) is a chronic autoimmune disease and is the most common form of inflammatory arthritis in the pediatric population. It is in fact a diverse group of diseases, including PsA, in the course of which damage to the articular cartilage and bone epiphyses occurs as a result of an inflammation. PsA is estimated to be responsible for $6-8 \%$ of all cases of JIA. z koniecznością uzupełnienia leczenia o fototerapię bądź leki ogólne, konwencjonalne lub biologiczne.

Podobnie jak u pacjentów dorosłych, łuszczycę łagodną definiuje się, gdy zmiany skórne zajmują poniżej 10\% całkowitej powierzchni skóry (BSA < 10\%), skala PASI nie przekracza 10 pkt oraz negatywny wpływ choroby na jakość życia według wskaźnika CDLQI jest mniejszy niż 10 pkt. Przekroczenie którejkolwiek wartości powyżej 10 upoważnia do rozpoznania łuszczycy o nasileniu umiarkowanym do ciężkiego. W wielu jednak pracach definiujących nasilenie łuszczycy u dzieci zaznacza się, że określenie postaci łagodnej, umiarkowanej bądź ciężkiej można już postawić na podstawie obliczenia BSA. Zgodnie z Menter i wsp. [9] uznaje się, że u dzieci można stosować analogiczny podział łuszczycy jak u pacjentów dorosłych na podstawie BSA, gdzie zajęcie zmianami łuszczycowymi skóry BSA < 3\% oznacza łuszczycę łagodną, BSA 3-10\% - łuszczycę umiarkowaną i BSA $>10 \%$ - łuszczycę ciężką. Określenie powierzchni skóry zajętej przez zmiany łuszczycowe określa się metodą dziewiątek odpowiednią do wieku dziecka. W szczególnych postaciach choroby, gdy wyżej wymienione wskaźniki (BSA, PASI) osiągają mniej niż 10 pkt, ale zmiany łuszczycowe lokalizują się w miejscach szczególnych (np. skóra owłosiona głowy, okolice narządów płciowych, ręce, stopy), bądź sprawiają dolegliwości podmiotowe (świąd, ból skóry) i wiążą się z ograniczeniem wykonywania codziennych czynności czy spełnianiem obowiązku szkolnego, przez co upośledzają jakość życia, można je zakwalifikować za odpowiadające ciężkiemu przebiegowi łuszczycy.

\section{CHOROBY WSPÓŁISTNIEJĄCE}

Łuszczyca jest chorobą ogólnoustrojową. U pacjentów dorosłych potwierdzono liczne choroby współistniejące, takie jak łuszczycowe zapalenie stawów (ŁZS), zespół metaboliczny, choroby układu krążenia, dyslipidemia, otyłość lub depresja. Wiele z tych współchorobowości może także towarzyszyć pacjentom pediatrycznym, choć danych na ten temat jest mniej i nadal prowadzone są badania. Dotychczasowe obserwacje kliniczne oraz wiedza płynąca z opublikowanych wyników badań nakazuje szersze spojrzenie na dziecko z łuszczycą i podjęcie odpowiedniego postępowania diagnostyczno-terapeutycznego, aby już na wczesnym etapie korygować wpływ łuszczycy na jakość życia oraz ogólny stan zdrowia.

\section{Łuszczycowe zapalenie stawów}

Młodzieńcze idiopatyczne zapalenie stawów (MIZS, juvenile idiopathic arthritis - JIA) jest przewlekłą chorobą o podłożu autoimmunologicznym i stanowi najczęstszą postać artropatii zapalnej w populacji pediatrycznej. Jest to w rzeczywistości zróżnicowana grupa chorób, do których zaliczane jest również łusz- 
In the course of JIA, the main symptom is inflammation of one or more joints with swelling, exudation, pain and limited mobility. Joint changes in some forms of JIA may be accompanied by fever, enlargement of the liver and/or spleen, lymphadenopathy, as well as changes in other organs, e.g., in the respiratory, digestive and circulatory systems [10-12]. Morning stiffness is one of the most clinically characteristic features of JIA. In children, symptoms are most often asymmetrical and concern large joints, mainly knees, while symmetrical changes in small joints of the hands are observed much less frequently. It is extremely important to make an early diagnosis of JIA due to the possibility of serious complications, primarily irreversible destruction of the joint, leading to disability. An equally serious complication is uveitis, which most often accompanies a non-articular form of JIA.

The incidence of arthritis in children with psoriasis is much lower than in the adult population and the disease affects approximately $0.7-1.2 \%$ of the population, with incidence increasing with age. In $80 \%$ of children with PsA, inflammatory changes in the joints precede the development of skin lesions, usually by 2-3 years. Most often, clinical symptoms appear in patients aged 2-3 years. or 10-12 years of age [11, 12]. As in other forms of JIA, the changes in juvenile PsA are arthritis with pain, swelling, and morning stiffness. In younger children, especially females, the changes mainly concern single joints with/or finger inflammation, while in older children (especially boys) enthesitis and spinal involvement are more frequently observed $[13,14]$. Due to the possibility of rheumatoid arthritis in patients with psoriasis, it is necessary to perform an in-depth diagnosis differentiating these two rheumatological diseases $[9,15]$. The coexistence of uveitis with PsA in the pediatric population is estimated at $1.5-25 \%$, therefore, in any case of eye pain, redness, blindness and photophobia, urgent ophthalmological consultation is necessary [12]. In children with psoriasis without arthritis, uveitis does not occur. Due to the frequent delay in the diagnosis of PsA in children, it is recommended to ask the patient and/or parents/guardians about joint pain, mobility problems, and periodic fever at each dermatological visit. Screening should be performed in order to enable a quick consultation in the field of pediatric rheumatology.

\section{Obesity and metabolic syndrome}

Symptoms of metabolic syndrome include obesity, hypertension, hypertriglyceridemia, hypercholesterolemia, and insulin resistance. Presence of three of these diseases allows for the diagnosis. All components of metabolic syndrome are risk factors for cardiovascular disease. On the basis of studies czycowe zapalenie stawów (ŁZS), w przebiegu których $\mathrm{w}$ wyniku procesu zapalnego dochodzi do uszkodzenia chrząstki stawowej i nasad kostnych. Ocenia się, że ŁZS odpowiada za 6-8\% wszystkich MIZS.

W przebiegu MIZS głównym objawem jest zapalenie jednego lub wielu stawów przebiegające z obrzękiem, wysiękiem, dolegliwościami bólowymi i ograniczeniem ruchomości. Zmianom stawowym w niektórych postaciach MIZS może towarzyszyć gorączka, powiększenie wątroby i/lub śledziony, limfadenopatia, a także zmiany w innych narządach, m.in. w układzie oddechowym, pokarmowym i krążenia [10-12]. Do najbardziej charakterystycznych klinicznie cech MIZS należy sztywność poranna. U dzieci objawy najczęściej są niesymetryczne i dotyczą dużych stawów, głównie kolanowych, natomiast symetryczne zmiany w drobnych stawach rąk są obserwowane zdecydowanie rzadziej. Niezwykle ważne jest ustalenie wczesnego rozpoznania MIZS ze względu na możliwość poważnych powikłań, przede wszystkim nieodwracalnej destrukcji stawu prowadzącej do niepełnosprawności. Równie poważnym powikłaniem jest zapalenie błony naczyniowej oka, które najczęściej towarzyszy nielicznostawowej postaci MIZS.

Częstość występowania zmian zapalnych stawów u dzieci z łuszczycą jest znacznie mniejsza niż u dorosłych i dotyczy około $0,7-1,2 \%$ populacji, wzrastając wraz z wiekiem. U 80\% dzieci z ŁZS zmiany zapalne w stawach poprzedzają rozwój zmian skórnych zazwyczaj o 2-3 lata. Najczęściej objawy kliniczne pojawiają się u pacjentów $\mathrm{w}$ wieku 2-3 lat lub 10-12 lat [11, 12]. Podobnie jak w innych postaciach MIZS, $\mathrm{w}$ młodzieńczym $\succeq Z S$ zmiany przebiegają $\mathrm{w}$ postaci zapalenia stawów z towarzyszącym bólem, obrzękiem i sztywnością poranną. U młodszych dzieci, szczególnie płci żeńskiej, zmiany dotyczą głównie pojedynczych stawów z/lub zapaleniem palców, natomiast u starszych (szczególnie chłopców) częściej obserwuje się zapalenie przyczepów ścięgnistych (enthesitis) oraz zajęcie kręgosłupa [13, 14]. Ze względu na możliwość występowania reumatoidalnego zapalenia stawów u chorych na łuszczycę konieczne jest przeprowadzenie wnikliwej diagnostyki różnicującej te dwie jednostki reumatologiczne [9, 15]. Wspólistnienie zapalenia błony naczyniowej oka z ŁZS w populacji dziecięcej ocenia się na 1,5-25\%, dlatego w każdym przypadku wystąpienia bólu oka, zaczerwienienia, utraty wzro$\mathrm{ku}$ i fotofobii konieczne jest pilne przeprowadzenie konsultacji okulistycznej [12]. Uveitis nie występuje u dzieci z łuszczycą bez towarzyszącego zapalenia stawów. Ze względu na częste opóźnienie w rozpoznaniu ŁZS u dzieci rekomenduje się, aby na każdej wizycie dermatologicznej pytać pacjenta i/lub rodziców lub opiekunów o dolegliwości bólowe stawów, problemy w poruszaniu się, okresowe gorączki. Skrining należy 
conducted so far, it has been shown that in children suffering from psoriasis, metabolic syndrome occurs more often than in the healthy population [16]. Pathogenetic data on psoriasis and obesity indicate that these are clinical conditions capable of causing systemic inflammation, hence their frequent coexistence and tendency to develop the metabolic syndrome. Adipose tissue is metabolically active and has the ability to secrete pro-inflammatory cytokines such as interleukins IL-1, IL-6, tumor necrosis factor (TNF), and adiponectin. The level of secretion of these proinflammatory proteins is significantly higher in obese subjects, while adiponectin (having anti-inflammatory properties) is significantly lower $[16,17]$. Obesity occurs in about $7 \%$ of children with psoriasis, and it is most common in children around 8 years of age. [18]. Currently available literature also allows obesity to be considered a risk factor for the development of psoriasis.

Bearing in mind the above, it should be indicated that children with psoriasis should be closely monitored for the development of obesity and other components of metabolic syndrome. If a child's weight is incorrect, a dietary consultation is necessary, as well as educating the parents/guardians and the patient in the healthy lifestyle (changing eating habits, physical activity), and in special cases it is advisable to consult a metabolic clinic of developmental age. Children with psoriasis during visits to dermatological offices/ wards should have their body weight, blood pressure and a lipid profile measured, as well as serum glucose concentration determined. Despite the lack of data on their coexistence in the pediatric population, but considering a frequent coexistence of psoriasis, obesity and nonalcoholic hepatic steatosis, it is also recommended to check liver parameters periodically in children with psoriasis. Presence of chronic inflammation resulting from psoriasis in childhood, as well as insulin resistance, endothelial damage and dyslipidemia, may explain the increased incidence of cardiovascular disease in this group of patients when they turn adult [19-21]. In the literature, this theory is referred to as the "psoriatic march".

\section{Psychological aspects and mental disorders}

Psoriasis has a particularly negative impact on children's quality of life. Conducted researches clearly stated that children very often felt stigmatized, had a sense of shame or embarrassment with their appearance [22]. These sensations along with common itching of the skin and the burdensome need to cover skin lesions, directly contribute to limiting children's physical activity and avoiding participation in recreational activities, which in turn interferes their networking with peers and may be responsible for mood changes, a sense of anxiety and development wykonywać w celu umożliwienia szybkiej konsultacji w zakresie reumatologii dziecięcej.

\section{Otyłość i zespół metaboliczny}

Do objawów zespołu metabolicznego zalicza się otyłość, nadciśnienie tętnicze, hipertrójglicerydemię, hipercholesterolemię oraz insulinooporność. Obecność trzech z wymienionych chorób upoważnia do jego rozpoznania. Wszystkie składowe zespołu metabolicznego są czynnikami ryzyka wystąpienia chorób układu krążenia. Na podstawie przeprowadzonych badań wykazano, że u dzieci chorujących na łuszczycę zespół metaboliczny występuje częściej w porównaniu ze zdrową populacją [16]. Dane patogenetyczne na temat łuszczycy oraz otyłości wskazują, że są to stany kliniczne zdolne do wywołania ogólnoustrojowego zapalenia, dlatego też obserwuje się ich częste współwystępowanie oraz skłonność do rozwoju zespołu metabolicznego. Tkanka tłuszczowa jest aktywna metabolicznie i ma zdolność do wydzielania cytokin prozapalnych, takich jak interleukina 1 (IL-1), IL-6, czynnik martwicy nowotworów (tumour necrosis factor - TNF) oraz adiponektyny. Poziom wydzielania tych białek prozapalnych jest istotnie wyższy u osób otyłych, natomiast adiponektyny (o właściwościach przeciwzapalnych) - istotnie niższy $[16,17]$. Otyłość występuje u około 7\% dzieci z łuszczycą, przy czym najczęściej pojawia się u dzieci około 8. roku życia [18]. Dane z piśmiennictwa pozwalają również uznać otyłość za czynnik ryzyka rozwoju łuszczycy.

Z tego względu należy wskazać, aby dzieci z łuszczycą podlegały ścisłej obserwacji w kierunku rozwoju otyłości i innych składowych zespołu metabolicznego. W przypadku stwierdzenia nieprawidłowej masy ciała dziecka konieczna jest konsultacja dietetyczna oraz edukacja rodziców lub opiekunów i pacjenta w zakresie prowadzenia zdrowego stylu życia (zmiana nawyków żywieniowych, aktywność fizyczna), a w szczególnych przypadkach wskazana jest konsultacja w poradniach metabolicznych wieku rozwojowego. Dzieci z łuszczyca podczas wizyt w gabinetach lub na oddziałach dermatologicznych powinny mieć określoną masę ciała, zmierzone ciśnienie tętnicze i wykonany lipidogram oraz oznaczone stężenie glukozy w surowicy. Ze względu na częste współistnienie łuszczycy, otyłości i niealkoholowej stłuszczeniowej choroby wątroby, mimo braku danych na ich współistnienie w populacji pediatrycznej, zaleca się również u dzieci z łuszczycą okresową kontrolę parametrów wątrobowych. Obecność w dzieciństwie przewlekłego stanu zapalnego wynikającego z łuszczycy, a także insulinooporność, uszkodzenie śródbłonka oraz dyslipidemia mogą tłumaczyć zwiększoną zapadalność na choroby układu krążenia w tej grupie chorych w wieku dorosłym [19-21]. W piśmiennictwie teoria ta występuje pod nazwą "marszu łuszczycowego". 
of depression. According to the literature, the above problems are especially severe in children who, apart from psoriasis, are also obese. One study [22] showed that children with psoriasis were at a significantly higher risk of developing depression, and in addition, these patients were more likely to be addicted to alcohol, drugs or eating disorders. They used antipsychotics, anxiolytics (e.g. benzodiazepines) more often than the control group. Depression is also more often diagnosed in family members of pediatric patients with psoriasis [23].

Thus, literature data indicate the need to provide psychological care for children with psoriasis, and in justified cases - also psychiatric care. Due to a frequent abuse of alcohol in adults with psoriasis, in the pediatric group, especially in adolescents, appropriate education should be provided about addictions and their negative impact on psoriasis. During outpatient dermatological visits or hospital stays, mental state of children should be regularly examined. The Quality of Life Questionnaire (CDLQI) may be used for that purpose.

\section{Non-specific inflammatory bowel diseases}

Non-specific inflammatory bowel diseases, such as Crohn's disease and ulcerative enteritis, occur 3-4 times more often in children with psoriasis compared to controls $[12,18]$. Currently, it is recommended to screen for these diseases in a group of patients with psoriasis, especially in the presence of gastrointestinal complaints, growth failure and unintentional weight loss.

\section{THERAPEUTIC AIMS}

Considering chronic nature of the disease, as well as existence of comorbidities, the aim of treating psoriasis in children is to inhibit inflammation and achieve clinical remission. At each stage of treatment, it is also necessary to educate the patient and his/her parents/guardians. Education should include providing patient/parents/caregivers with information on disease pathogenesis, triggering agents (table 1), natural history, potential comorbidities, available treatment options, and the impact of lifestyle choices on the course of psoriasis. The patient and his/her family should be informed about the legitimacy of using psychological care. It is advisable to provide information on regular dental checkups, as well as provide dietary recommendations. Education should be carried out in all patients, regardless of the severity of their disease, at each visit to a specialist. Patients should also be made aware of the existence of patient associations, support groups or foundations

\section{Aspekty psychologiczne i zaburzenia psychiatryczne}

Łuszczyca ma szczególnie negatywny wpływ na jakość życia dzieci. W badaniach jednoznacznie określono, że dzieci bardzo często odczuwają stygmatyzację, poczucie wstydu czy zażenowanie swoim wyglądem [22]. Te odczucia oraz, dodatkowo, często odczuwany świąd skóry i uciążliwa konieczność zakrywania zmian skórnych bezpośrednio przyczyniają się do ograniczenia aktywności fizycznej dzieci i unikania uczestniczenia w zajęciach rekreacyjnych, co z kolei zaburza nawiązywanie kontaktów z rówieśnikami i może odpowiadać za zmiany nastroju, poczucie lęku i rozwój depresji. Zgodnie z piśmiennictwem powyższe problemy są szczególnie nasilone $\mathrm{u}$ dzieci, które poza łuszczycą są również otyłe. W jednym z badań [22] stwierdzono, że u dzieci z łuszczycą ryzyko rozwoju depresji jest istotnie wyższe, dodatkowo pacjenci ci są bardziej narażeni na uzależnienie od alkoholu, leków czy zaburzenia żywienia. Częściej niż w grupie kontrolnej przyjmują leki antypsychotyczne lub przeciwlękowe (np. benzodiazepiny). Depresja częściej rozpoznawana jest też u członków rodzin pacjentów pediatrycznych z łuszczycą [23].

Dane z piśmiennictwa wskazują na konieczność objęcia dzieci z łuszczycą opieką psychologiczną, a w uzasadnionych przypadkach - psychiatryczną. Ze względu na częste nadużywanie alkoholu u dorosłych chorych na łuszczycę, w grupie pediatrycznej, szczególnie u nastolatków, należy prowadzić odpowiednią edukację dotyczącą uzależnień oraz ich negatywnego wpływu na łuszczycę. Podczas ambulatoryjnych wizyt dermatologicznych bądź pobytów szpitalnych stan psychiczny dzieci powinien być regularnie badany, do czego może służyć m.in. kwestionariusz jakości życia (CDLQI).

\section{Nieswoiste zapalne choroby jelit}

Nieswoiste choroby zapalne jelit, do których należy choroba Leśniowskiego-Crohna i wrzodziejące zapalenie jelit, występują 3-4-krotnie częściej u dzieci z łuszczycą w porównaniu z grupą kontrolną $[12,18]$. Obecnie rekomenduje się przeprowadzanie skriningu w kierunku tych chorób u pacjentów z łuszczycą, szczególnie w przypadku występowania dolegliwości ze strony przewodu pokarmowego, upośledzenia wzrostu i przy stwierdzeniu niezamierzonej utraty masy ciała.

\section{CELE TERAPEUTYCZNE}

Ze względu na przewlekły charakter choroby, a także współwystępowanie chorób towarzyszących, celem leczenia łuszczycy u dzieci jest zahamowanie stanu zapalnego i uzyskanie stanu remisji klinicznej. Na każdym etapie terapii konieczne jest także prowadzenie edukacji 
Table I. Factors triggering and/or exacerbating psoriasis in children $[2,9]$

\begin{tabular}{l}
\hline Emotional stress \\
\hline High body mass index (BMI) \\
\hline Skin injuries (Koebner phenomenon) - abrasions, tattoos, \\
vaccinations, etc. \\
\hline Exposure to tobacco smoke \\
\hline Infections with group A, C and G streptococci, B and D \\
$\beta$-hemolytic streptococci, infections with Pseudomonas, \\
Klebsiella and Bacillus cereus \\
\hline Viral infections: herpes, chickenpox, shingles, HIV \\
\hline Infections with yeast-like fungi: Candida albicans, \\
Malassezia spp. \\
\hline Caries, chronic tonsilitis and/or paranasal sinusitis \\
\hline Kawasaki disease \\
\hline Discontinuation of systemic glucocorticosteroids \\
\hline Treatment with TNF inhibitors (paradoxical reaction in course \\
of treatment of juvenile idiopathic arthritis, and inflammatory \\
bowel diseases) \\
\hline Pharmacotherapy (rarely in children): non-steroid anti- \\
inflammatory drugs, $\beta$-blockers, lithium, anti-malaria drugs, \\
tetracyclines
\end{tabular}

that work for patients and help them in their daily lives.

The patient and his/her parents/guardians should also be informed that not in all cases of psoriasis it is possible to obtain complete clearance of lesions. In children, therapeutic aims are analogous to those indicated in the Polish Dermatological Society Recommendations for adult patients [1]. We consider a therapeutic effect to be satisfactory when a treatment results in reduction of the PASI index by at least 90\% (PASI 90). As suggested by the Polish Dermatological Society for adults [1], we recommend that reduction of skin lesions between $75 \%$ and $90 \%$ was satisfactory only if the CDLQI index is reduced to a value below 5 . However, no reduction of lesions by at least $75 \%$ (failure to obtain the PASI75 result) during 3-4 months from the start of treatment (depending on the provisions in the SmPC of individual drugs) with a persistent reduction in the quality of life CDLQI > 5 points, should be an indication for a change or modification of the therapy, e.g., increasing dose of the drug. The same procedure should be implemented if, during the treatment, there is an increase in skin lesions measured by the PASI index (increase in PASI by at least 25\%) (fig. 1). After obtaining a satisfactory clinical effect, treatment should be continued, because the essence of the therapeutic process is to obtain permanent control of the disease. Similarly to adult patients, after completing systemic treatment, we suggest reconsidering the therapy with an increase in PASI > 5 and/or CDLQI > 5 [1].
Tabela I. Czynniki prowokujące i/lub zaostrzające łuszczyce u dzieci $[2,9]$

\begin{tabular}{l}
\hline Stres emocjonalny \\
\hline Wysoki wskaźnik masy ciała (BMI) \\
\hline Urazy skóry (zjawisko koebneryzacji) - otarcia, tatuaże, \\
szczepienia itp. \\
\hline Ekspozycja na dym tytoniowy \\
\hline Infekcje paciorkowcowe grupy A, C i G, paciorkowce \\
$\beta$-hemolizujące B i D, zakażenia Pseudomonas, Klebsiella oraz \\
Bacillus cereus \\
\hline Infekcje wirusowe: opryszczka, ospa wietrzna, półpasiec, HIV \\
\hline Zakażenia grzybami drożdżopodobnymi: Candida albicans, \\
Malassezia spp. \\
\hline Próchnica, przewlekłe zapalenie migdałów i/lub zatok \\
przynosowych \\
\hline Choroba Kawasakiego \\
\hline Odstawienie glikokortykosteroidów stosowanych ogólnie \\
\hline Leczenie inhibitorami TNF (reakcja paradoksalna w trakcie \\
leczenia młodzieńczego idiopatycznego zapalenia stawów lub \\
chorób zapalnych jelit) \\
\hline Stosowanie leków (rzadko u dzieci): niesteroidowe leki \\
przeciwzapalne, $\beta$-blokery, lit, leki przeciwmalaryczne, \\
tetracykliny
\end{tabular}

pacjenta oraz jego rodziców lub opiekunów. Edukacja powinna obejmować przekazanie pacjentowi lub rodzicom albo opiekunom informacji na temat patogenezy choroby, czynników prowokujących (tab. 1), naturalnego przebiegu, potencjalnych chorób współwystępujących, dostępnych opcji terapeutycznych oraz wpływu stylu życia na przebieg łuszczycy. Należy poinformować pacjenta i jego rodzinę o zasadności skorzystania z opieki psychologicznej. Wskazane jest przekazanie informacji na temat regularnych kontroli stomatologicznych, a także udzielenie zaleceń dietetycznych. Edukacja powinna być przeprowadzana u wszystkich pacjentów, niezależnie od nasilenia procesu chorobowego, na każdej wizycie u lekarza specjalisty. Pacjenci powinni być również poinformowani o istnieniu stowarzyszeń pacjenckich, grup wsparcia bądź fundacji działających na rzecz pacjentów i pomagających im w codziennym życiu.

Pacjenta i jego rodziców lub opiekunów należy także poinformować, że nie w każdym przypadku łuszczycy jest możliwe uzyskanie całkowitego ustąpienia zmian chorobowych. U dzieci cele terapeutyczne są analogiczne do wskazanych w rekomendacjach Polskiego Towarzystwa Dermatologicznego dla pacjentów dorosłych [1]. Za skuteczny efekt terapeutyczny uznaje się sytuację kliniczną, gdy po zastosowaniu leczenia uzyskuje się redukcję wskaźnika PASI przynajmniej o 90\% (PASI 90). Zgodnie z rekomendacjami Polskiego Towarzystwa Dermatologicznego dla osób dorosłych [1] rekomendujemy, aby redukcje zmian skórnych między 75\% a 90\% uznać za satysfakcjonująca jedynie w przypadku redukcji wskaźnika 


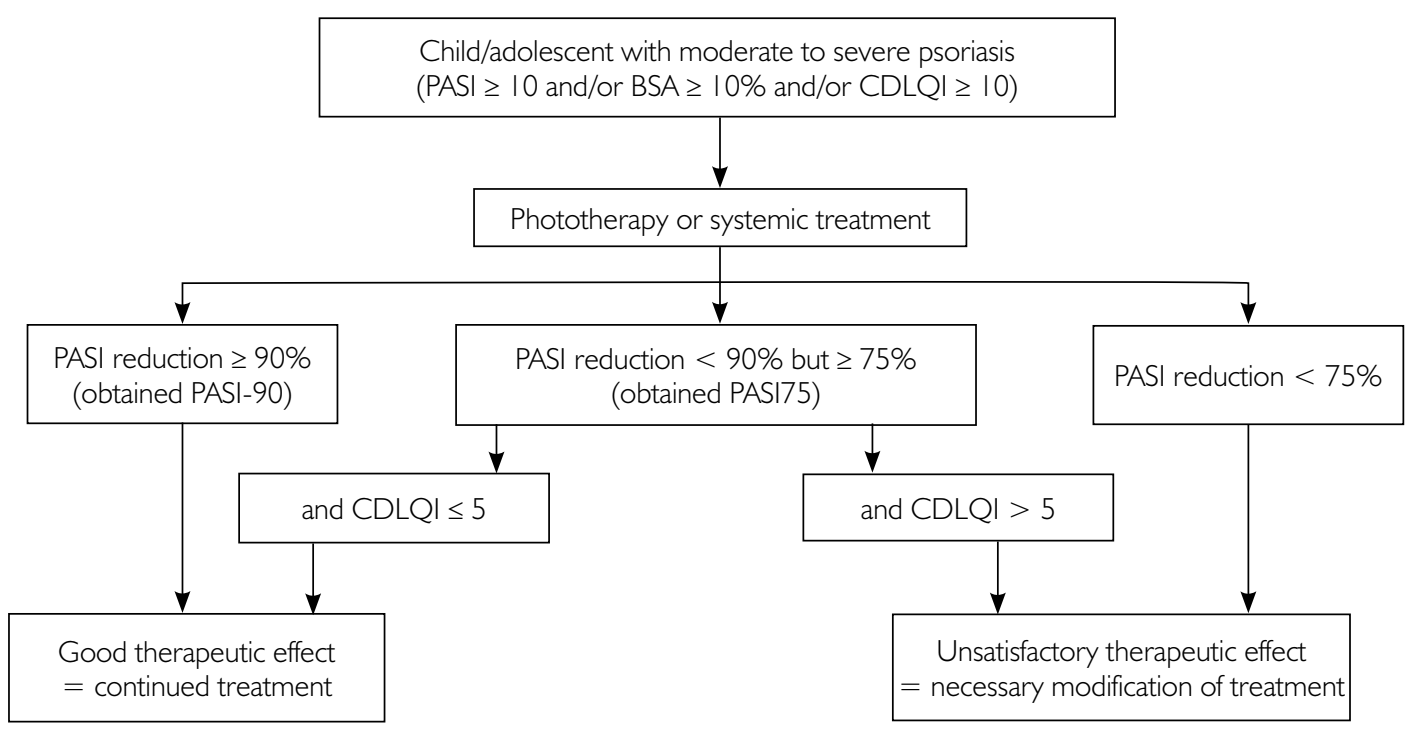

Figure I. Scheme of treatment, taking into account therapeutic aims, in the pediatric population of psoriasis patients

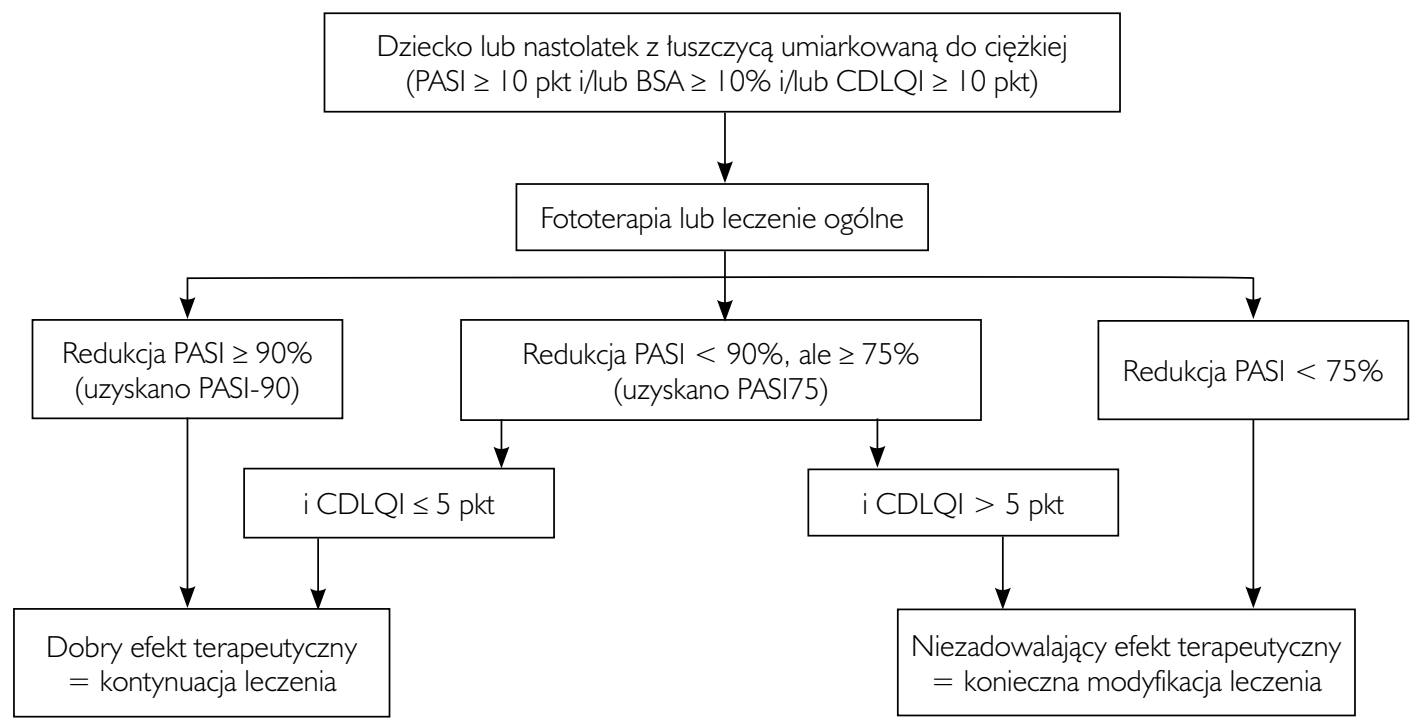

Rycina I. Schemat postępowania leczniczego uwzględniającego cele terapeutyczne w populacji pediatrycznej chorych na łuszczycę

The choice of the next drug is an individual decision. The suggested management scheme applies mainly to patients with moderate or severe psoriasis. In the treatment of the mild form, local treatment should be used, taking into account the possibility of systemic therapy in special clinical situations, i.e., in face of a significant impairment of the quality of life and involvement of particular areas.

\section{TOPICAL TREATMENT}

Local treatment as monotherapy is used in children with mild forms of psoriasis (BSA $<10 \%$, PASI $<10$ ) and as an adjunct therapy to phototherapy and systemic therapies. Local treatment of psoriasis must be planned individually, depending on the age of the
CDLQI do wartości poniżej 5. Brak redukcji zmian chorobowych przynajmniej o 75\% (nieuzyskanie wyniku PASI75) w czasie 3-4 miesięcy od rozpoczęcia leczenia (w zależności od zapisów w charakterystyce poszczególnych leków) przy utrzymującym się obniżeniu jakości życia CDLQI > 5 pkt powinno być wskazaniem do zmiany terapii lub jej modyfikacji, np. zwiększenia dawki leku. Takie samo postępowanie należy wdrożyć, jeśli w trakcie leczenia dochodzi do nasilenia zmian skórnych mierzonego wskaźnikiem PASI (wzrost PASI przynajmniej o 25\%) (ryc. 1). Po uzyskaniu zadowalającego efektu klinicznego leczenie należy kontynuować, gdyż istotą procesu terapeutycznego jest uzyskanie trwałej kontroli choroby. Po zakończeniu leczenia ogólnego, podobnie jak u pacjentów dorosłych, proponujemy ponowne rozważenie terapii przy wzroście PASI $>5$ i/lub CDLQI $>5$ 
child, extent of lesions and their location. The socioeconomic situation of the family and the patient's lifestyle (physical activity, extracurricular activities) should also be taken into account. When choosing a treatment, the patient's preferences should be based on the patient's and his/her parents/guardians' ability to adapt to the principles of treatment, as well as on the quality of life understood as the impact of the disease on the psyche and the ability to function in school and in the family. This is especially true when prescribing medication to adolescents.

Contrary to the presence of many recommendations for general treatment in psoriasis, literature offers no unambiguous guidelines for local treatment in the pediatric population. In clinical practice, there are many uncertainties about how topical therapy should be administered, especially in terms of its duration, discontinuation, maintenance therapy, as well as combined or rotational methods. It is recognized that the basic principle of local therapy is an intense use of drugs in the first phase (induction), usually lasting several weeks (about 4-8), and then the use of maintenance treatment, the length of which is individually decided by the attending physician.

During the induction phase, the aim is to obtain absorption of psoriatic lesions, and in the maintenance phase, to delay disease relapse and prolong clinical remission. Initially, it is justified to use preparations of greater potency, followed by application of weaker drugs, sometimes every other day, and then, for example, twice a week. Regardless of the treatment method used, the therapy should be supplemented with emollients. Due to limited data in the literature and sparse clinical trials, we conduct the treatment based largely on clinical experience [24]. When treating children topically, it is important to remember about a different skin structure in pediatric patients, which results in greater systemic absorption of topical drugs. In the youngest children, folds of the adhering skin should be taken into account and the possibility of unintentional occlusions (diapers). Also in this case, absorption of a drug into the body may be increased, but there is also a greater chance of irritation. In the youngest patients, there is also a risk that they will transfer a topical drug to other places, especially to the face, eyes or mouth.

\section{Keratolytic products}

In the event of the occurrence of a scale, its removal is always the first aim of treatment, ensuring on subsequent steps a better penetration of an antiinflammatory active substance, leading to increased clinical effectiveness. For this purpose, preparations containing urea, salicylic acid and lactic acid are mainly used. The use of salicylic acid in children requires special caution due to the possibility of in-
[1]. Wybór kolejnego leku jest decyzją indywidualną. Proponowany schemat postępowania dotyczy przede wszystkim pacjentów z łuszczycą z umiarkowanym lub dużym nasileniem zmian. W leczeniu postaci łagodnej stosujemy leczenie miejscowe, z uwzględnieniem możliwości włączenia terapii ogólnej w szczególnych sytuacjach klinicznych, tj. istotnego upośledzenia jakości życia i zajęcia miejsc szczególnych.

\section{LECZENIE MIEJSCOWE}

Leczenie miejscowe jako monoterapia jest stosowane $\mathrm{u}$ dzieci $\mathrm{w}$ łagodnych postaciach łuszczycy (BSA $<10 \%$, PASI < 10) oraz jako leczenie wspomagające przy stosowaniu fototerapii oraz terapii ogólnych. Miejscowe leczenie łuszczycy musi być zaplanowane indywidualnie, w zależności od wieku dziecka, rozległości zmian chorobowych oraz ich lokalizacji. Należy również uwzględnić sytuację socjoekonomiczną rodziny oraz styl życia pacjenta (aktywność fizyczna, zajęcia dodatkowe). Przy wyborze terapii należy opierać się na preferencjach pacjenta, możliwościach dostosowania się pacjenta oraz jego rodziców lub opiekunów do zasad leczenia, a także jakości życia rozumianej jako wpływ choroby na psychikę oraz możliwość funkcjonowania w szkole i w rodzinie. Jest to szczególnie ważne przy włączaniu leków nastolatkom.

W przeciwieństwie do wielu rekomendacji dotyczących leczenia ogólnego w łuszczycy, nie ma w piśmiennictwie jednoznacznych wytycznych dotyczących leczenia miejscowego w populacji pediatrycznej. W praktyce klinicznej istnieje wiele niewiadomych dotyczących sposobu prowadzenia terapii miejscowej, szczególnie czasu trwania, sposobu przerwania leczenia, terapii podtrzymującej bądź metod łączonych czy rotacyjnych. Uznaje się, że podstawową zasadą terapii miejscowej jest intensywne stosowanie leków w pierwszej fazie (indukcja), trwającej zazwyczaj kilka tygodni (ok. 4-8), a następnie stosowanie leczenia podtrzymującego, o długości którego indywidualnie decyduje lekarz prowadzący.

$\mathrm{W}$ fazie indukcji celem jest uzyskanie wchłonięcia się zmian łuszczycowych, a w fazie podtrzymującej - opóźnienie nawrotu choroby i wydłużenie okresu remisji klinicznej. Początkowo zasadne jest stosowanie preparatów o większej sile działania, a następnie aplikacja leków słabszych, niekiedy co drugi dzień, następnie np. 2 razy w tygodniu. Niezależnie od stosowanej metody leczenia, terapię uzupełnia się emolientami. Ze względu na ograniczone dane w piśmiennictwie i nieliczne badania kliniczne leczenie prowadzi się, opierając się znacznie na doświadczeniu klinicznym [24]. Przy leczeniu miejscowym u dzieci powinno się pamiętać o odmiennej budowie skóry u pacjentów pediatrycznych, co skutkuje większym wchłanianiem ogólnoustrojowym leków 
toxication. Absorption of salicylic acid is the highest in children under 2 years of age, therefore in this age group it should not be used at all [25]. In other age groups, it is recommended to use salicylic acid for 1-3 days in the following concentrations: $1.5-2 \%$ (3-6 years of age), 2-3\% (7-14 years of age), 5\% (> 14 years of age) [26].

\section{Anthralin}

According to recommendations of Polish Dermatological Society [1], anthralin (cignoline) is a standard in the local therapy of psoriasis in children, especially in cases of more severe skin lesions. However, the drug's physical and cosmetic properties should be considered and it should be implemented only after consultation with the patient and the parent/guardian. The mechanism of action of anthralin is the impairment of keratinocyte mitosis and DNA synthesis [27]. Its effectiveness in psoriasis has been studied mainly in the adult population. One study [28] analyzed 60 children with psoriasis aged 3-18 years who were treated with cignolin (concentration $0.01-4 \%$ ) in minute therapy (exposure time from 15 to 45 minutes). $3.7 \%$ of patients assessed its effectiveness as very good, $69.5 \%$ of patients reported significant improvement, while $4.9 \%$ of patients reported definite dissatisfaction. The mean remission period after the end of treatment was 5.5 months. The most common side effect was local skin irritation. A similar therapeutic effect with the use of anthralin is reported by Zvulunov et al. [29]. On the other hand, Oostveen et al. [30] in a prospective study (34 children aged 3-17) assessed the efficacy of anthralin (mean treatment duration 11 weeks) after previous failure of treatment with topical glucocorticosteroids and calcipotriol. Clinical improvement was demonstrated with a reduction in baseline PASI by $69 \%$ and an improvement in CDLQI by 5.1 points. Patients reported that the treatment was well tolerated without any significant side effects.

Anthralin should not be applied to intertriginous areas or to the skin of the face or neck. Taking into account its efficacy and systemic safety, anthralin can be considered as the standard of topical treatment in the pediatric population, especially in the youngest age groups. However, due to its cosmetic properties, it is mainly used in hospitals or as a non-first/second line treatment [31]. The most common side effects include skin irritation, burning, itching and reddening of the skin, and stained clothes or bedding. The proposed application consists either in the use of higher concentrations $(0.5-2 \%)$ in the minute therapy (from several to several dozen minutes) for localized psoriasis lesions, or lower concentrations (0.05-0.5\%) for all skin lesions during the whole night. The drug may miejscowych. U najmłodszych dzieci należy pamiętać o znacznym przyleganiu fałdów skóry do siebie i możliwości nieświadomego zastosowania okluzji (pieluchy). Również w tym przypadku może dochodzić do zwiększonego wchłaniania leku do organizmu, a także istnieje większa szansa na wystąpienie podrażnienia. U najmłodszych pacjentów istnieje też ryzyko przenoszenia przez nich leku miejscowego w inne miejsca, szczególnie na twarz, do oczu lub jamy ustnej.

\section{Preparaty keratolityczne}

W przypadku wystąpienia łuski jej usunięcie jest zawsze pierwszym celem leczenia, zapewniajacym $\mathrm{w}$ następnym etapie lepsze przenikanie czynnej substancji przeciwzapalnej, co prowadzi do zwiększenia efektywności klinicznej. W tym celu głównie stosuje się preparaty zawierające mocznik, kwas salicylowy oraz kwas mlekowy. Stosowanie kwasu salicylowego u dzieci wymaga szczególnej rozwagi ze względu na możliwość intoksykacji. Absorpcja kwasu salicylowego jest największa u dzieci do 2. roku życia, stąd też $\mathrm{w}$ tej grupie wiekowej nie powinno się go w ogóle stosować [25]. W pozostałych grupach wiekowych zaleca się stosowanie kwasu salicylowego przez 13 dni w następujących stężeniach: 1,5-2\% (3-6 lat), 2-3\% (7-14 lat), 5\% (> 14 lat) [26].

\section{Antralina}

Zgodnie z rekomendacjami Polskiego Towarzystwa Dermatologicznego [1] antralina (cignolina) jest standardem w miejscowej terapii łuszczycy u dzieci, zwłaszcza w przypadkach bardziej nasilonych zmian skórnych. Należy jednak pamiętać o jej właściwościach fizycznych i kosmetycznych oraz wdrażać ją dopiero po uzgodnieniu z pacjentem oraz rodzicem lub opiekunem. Mechanizm działania antraliny polega na upośledzeniu mitoz keratynocytów oraz syntezy DNA [27]. Jej skuteczność w łuszczycy była badana głównie $\mathrm{u}$ osób dorosłych. W jednym z badań [28] przeprowadzono analizę 60 dzieci z łuszczycą w wieku 3-18 lat, które leczone były cygnoliną (stężenie 0,01-4\%) $\mathrm{w}$ terapii minutowej (czas ekspozycji od 15 do $45 \mathrm{mi}-$ nut). 3,7\% pacjentów oceniło jej skuteczność na bardzo dobrą, u 69,5\% chorych stwierdzono dobrą poprawę, natomiast $4,9 \%$ pacjentów zgłaszało zdecydowane niezadowolenie. Średni okres remisji po zakończeniu leczenia wynosił 5,5 miesiąca. Do najczęstszych działań niepożądanych zaliczono miejscowe podrażnienie skóry. Podobne działanie terapeutyczne z zastosowaniem antraliny podaje Zvulunov i wsp. [29]. Oostveen i wsp. [30] w przeprowadzonym badaniu prospektywnym (34 dzieci w wieku 3-17 lat) oceniali skuteczność antraliny (średni czas leczenia 11 tygodni) po wcześniejszym niepowodzeniu leczenia miejscowy- 
be safely combined with UVB irradiation (Ingram's method). Anthralin therapy should always be supplemented with the application of emollients containing urea in a concentration of 5-15\%. Due to the fact that both the prescription and ready-made anthalin formulations contain salicylic acid, they should not be used in the group up to 2 years of age, and with great care, on small areas of the skin in older children. Alternatively, instead of salicylic acid, the addition of lactic or ascorbic acid can be recommended.

\section{Wood tars}

The mechanism of action of wood tar is not fully understood. Its ability to inhibit DNA synthesis and reduce keratinocyte proliferation has been suggested. Tars are included in prescription preparations, but they can also be an addition to ready-made products, mainly shampoos. Tar preparations in a concentration of $2-5 \%$ can be used as monotherapy, but most often they are recommended in combination with UVB irradiation (Goeckerman's method) [32]. One retrospective study showed that the Goeckerman's method used for 12 days in the treatment of children with plaque and small patches of psoriasis was effective in $64 \%$ of patients, including $82 \%$ in whom the effect persisted for 4 months, and $43 \%$ with the effect lasting for a year [33]. On the other hand, another retrospective study by Kortuem et al. [32] showed that the combined treatment with tar and phototherapy was effective in all patients, and long-term remission was maintained in $85 \%$ of them ( 2.6 years). Side effects after wood tar application include local skin irritation, folliculitis, contact dermatitis and phototoxicity. Staining of clothes, bedding, etc is possible. The Polish Dermatological Society does not recommend the use of this treatment regimen. Due to the potential risk of carcinogenesis after the combined use of tar and phototherapy, the Society does not recommend this method of treatment in combination with UVB in children. This thesis is confirmed by tests showing the presence of metabolites of tar in the urine, as well as chromosomal aberrations in lymphocytes in children treated with this method [34-37]. If no other treatment options are available, tar alone or in combination with phototherapy in the pediatric population should be used on an individual basis, taking into account the benefit/risk ratio.

\section{Glucocorticosteroids}

In everyday clinical practice, topical glucocorticosteroids (GSCs) are the most frequently prescribed drugs in the local treatment of psoriasis, including in the pediatric population, despite the lack of clinical trials. When choosing GCSs, one should always take into account potency of the drug, the substrate, the mi glikokortykosteroidami i kalcypotriolem. Wykazano poprawę kliniczną z redukcją PASI wyjściowego o $69 \%$ i poprawę w zakresie CDLQI o 5,1 pkt. Pacjenci podawali dobrą tolerancję leczenia, bez wystąpienia istotnych działań niepożądanych.

Stosując antralinę, nie należy jej aplikować w okolice wyprzeniowe ani na skórę twarzy lub szyi. Ze względu na skuteczność i bezpieczeństwo ogólnoustrojowe antralina może być uznana za standard leczenia miejscowego w populacji dziecięcej, szczególnie w najmłodszych grupach wiekowych. Ze względu jednak na właściwości kosmetyczne stosowana jest głównie $\mathrm{w}$ lecznictwie szpitalnym lub jako leczenie kolejnego wyboru [31]. Do najczęstszych działań niepożądanych zalicza się podrażnienie skóry, pieczenie, świąd i zaczerwienienie skóry oraz brudzenie ubrań czy pościeli. Proponowana aplikacja polega na stosowaniu wyższych stężeń $(0,5-2 \%)$ w terapii minutowej (od kilku do kilkudziesięciu minut) na zlokalizowane zmiany łuszczycowe lub niższych stężeń $(0,05-0,5 \%)$ na wszystkie zmiany skórne na całą noc. Bezpiecznie jest też łączenie z naświetlaniami UVB (metoda Ingrama). Leczenie antraliną powinno być zawsze uzupełnione aplikacją emolientów zawierających mocznik w stężeniu 5-15\%. Ze względu na fakt, że zarówno recepturowe, jak i gotowe formulacje antraliny zawierają kwas salicylowy nie powinno się ich stosować $\mathrm{w}$ grupie do 2 . roku życia i z dużą ostrożnością, na niewielkie powierzchnie skóry u dzieci w starszym wieku. Alternatywnie zamiast kwasu salicylowego można zalecić dodanie kwasu mlekowego lub askorbinowego.

\section{Dziegcie}

Mechanizm działania dziegci nie jest do końca poznany, sugeruje się ich zdolność do hamowania syntezy DNA oraz redukcji proliferacji keratynocytów. Zawarte są $\mathrm{w}$ preparatach recepturowych, ale mogą też stanowić dodatek do produktów gotowych, głównie szamponów. Preparaty dziegciowe w stężeniu 2-5\% mogą być stosowane $\mathrm{w}$ monoterapii, ale najczęściej zaleca się je $\mathrm{w}$ skojarzeniu $\mathrm{z}$ naświetlaniami UVB (metoda Goeckermana) [32]. W jednym badaniu retrospektywnym wykazano, że metoda Goeckermana stosowana przez 12 dni w leczeniu dzieci z łuszczycą plackowatą i drobnogrudkową przynosi dobry efekt u $64 \%$ chorych, z czego u $82 \%$ efekt utrzymywał się w 4-miesięcznej obserwacji, natomiast przez cały rok - $\mathrm{u} 43 \%$ badanych [33]. $\mathrm{W}$ innym badaniu retrospektywnym przeprowadzonym przez Kortuem i wsp. [32] wykazano, że leczenie skojarzone dziegciami i fototerapią przyniosło efekt u wszystkich chorych, a u $85 \%$ z nich utrzymywała się długotrwała remisja (2,6 roku). Do działań niepożądanych po aplikacji dziegci zalicza się miejscowe podrażnienie skóry, zapalenie mieszków włosowych, kontaktowe zapalenie skóry i fototoksyczność. Może 
child's age and extent of lesions, bearing in mind the increased absorption of topical preparations in children, especially in the youngest age groups, and the possibility of inhibiting the hypothalamic-pituitaryadrenal axis. GCSs can be used both at the beginning of the disease as an induction treatment, and later as a maintenance treatment. Topical GCSs are applied once a day, supplementing the treatment with emollients, which allows us to reduce the number of side effects and reduce consumption of the drug. Strength of tGCSs should be chosen depending on location of lesions, avoiding strong CGSs on the face, neck, and in anogenital areas. The rebound effect after discontinuation of GCSs is well known, therefore it is so important to implement maintenance treatment. It can be carried out with a preparation with a lower potency, used in individually selected, variable schedules, e.g., every two days, twice a week or in "weekend" therapy on Saturdays and Sundays. There are very few studies in the literature describing efficacy and safety of tGCSs in children with psoriasis. The study by Frangos and Kimball [38] demonstrated the effectiveness of clobetasol in foam (2-week application), while also noting the reversible suppression of the hypothalamic-pituitary-adrenal axis in children under 12 years of age, and the lack of this effect in patients $>12$ years of age In another study in 11 children, halobetasole was used for 14 days. A significant clinical improvement was demonstrated in $90.9 \%$ of patients $[2,39,40]$.

In children, preparations with a lower potency, in creams or liquids, should be used. In justified cases, keratolytic preparations or a combination of tGCSs with salicylic acid can be initially applied before using tGCSs.

Treatment with tGCSs should be carried out under strict dermatological control due to a possibility of numerous side effects, including stretch marks, atrophy, hypertrichosis, acne, folliculitis, hyperpigmentation and discoloration, telangiectasia and tachyphylaxis. Systemic symptoms (e.g., suppression of the hypothalamic-pituitary-supernatural axis, growth retardation, hypertensive crisis) are generally not observed at present. With the correct use of drugs, under the supervision of a physician, in addition to local emollients, there are usually no serious side effects, even if these drugs are used for a long time. The key is therefore the appropriate cooperation between the doctor and the patient and establishing a reasonable treatment plan. tGCSs can be used together with other topical drugs, e.g. calcipotriol, and with systemic treatments, including irradiation of the skin with NB-UVB rays (311 $\mathrm{nm}$ ) or PUVA, but also during systemic treatment with conventional or biological drugs. również dojść do zabrudzenia ubrań, pościeli itd. Polskie rekomendacje nie zalecają stosowania tego schematu leczenia. Ze względu na potencjalne ryzyko kancerogenezy po łącznym stosowaniu dziegci i fototerapii Polskie Towarzystwo Dermatologiczne nie rekomenduje stosowania tej metody leczenia w połączeniu z UVB u dzieci. Potwierdzeniem tej tezy są badania wykazujące obecność metabolitów dziegci w moczu, a także aberracje chromosomalne w limfocytach u dzieci leczonych tą metodą [34-37]. Dziegcie w monoterapii lub w skojarzeniu $\mathrm{z}$ fototerapią powinny być stosowane u dzieci indywidualnie, po rozważeniu potencjalnych korzyści i ryzyka. Te metody rezerwuje się zazwyczaj dla przypadków, w których nie jest możliwe zastosowanie innych metod terapeutycznych.

\section{Glikokortykosteroidy}

Miejscowe glikokortykosteroidy (mGKS) w codziennej praktyce klinicznej stanowią najczęściej przepisywane leki w leczeniu miejscowym łuszczycy, w tym w populacji dziecięcej, mimo braku przeprowadzonych badań klinicznych. Przy wyborze mGKS należy zawsze wziąć pod uwagę siłę działania leku, podłoże, wiek dziecka oraz rozległość zmian chorobowych, pamiętając o zwiększonym wchłanianiu miejscowych preparatów u dzieci, szczególnie w najmłodszych grupach wiekowych, oraz o możliwości zahamowania osi podwzgórze-przysadkanadnercza. mGKS mogą być stosowane zarówno na początku choroby jako leczenie indukujące, a także w późniejszym okresie jako leczenie podtrzymujące. mGKS aplikuje się raz dziennie, uzupełniając terapię emolientami, co pozwala na zmniejszenie liczby działań niepożądanych, a także ograniczenie zużycia leku. Siłę działania mGKS wybiera się także w zależności od lokalizacji zmian chorobowych, unikając silnych mGKS na twarz, szyje, okolice wyprzeniowe oraz anogenitalne. Powszechnie znany jest efekt „z odbicia” po odstawieniu mGKS, dlatego tak ważne jest wdrożenie leczenia podtrzymującego. Może być ono prowadzone preparatem o mniejszej sile działania, stosowanym $\mathrm{w}$ indywidualnie dobranych, różnych schematach, np. co 2 dni, 2 razy w tygodniu lub w terapii „weekendowej” w soboty i niedziele. $\mathrm{W}$ piśmiennictwie jest bardzo niewiele badań opisujących skuteczność i bezpieczeństwo stosowania mGKS u dzieci z łuszczycą. W badaniu przeprowadzonym przez Frangosa i Kimballa [38] wykazano skuteczność klobetazolu w pianie (aplikacja 2-tygodniowa), odnotowując jednocześnie odwracalną supresję osi podwzgórze-przysadka-nadnercza u dzieci poniżej 12 lat oraz brak tego efektu u pacjentów powyżej 12 lat. W kolejnym badaniu przeprowadzonym u 11 dzieci stosowano halobetazol przez 14 dni. U 90,9\% chorych stwierdzono istotną poprawę kliniczną $[2,39,40]$.

U dzieci staramy się stosować preparaty o niższej sile działania w podłożach kremowych lub płynach. W uza- 


\section{Topical calcineurin inhibitors}

Topical calcineurin inhibitors ( $\mathrm{tCl}$ ), i.e., tacrolimus ointment and pimecrolimus cream, are approved for the treatment of atopic dermatitis in children over 2 years of age. In line with recommendations of many authors, as well as our own experience, we recommend them as the first-line treatment for psoriatic lesions located on the face, in genital area and in intertriginous areas $[9,28,41]$. There is very little research on the use of $\mathrm{tCI}$ in children with psoriasis. One study investigated the effectiveness of tacrolimus in the treatment of psoriasis on the face and in intertriginous areas (11 children, 6-15 years of age). In 8 patients, a very good therapeutic effect was obtained after 30 days of treatment [42]. Similar observations were also made by other authors, and these were either retrospective analyzes or case reports. The clinical effect was reported to be visible after approximately 2 weeks of treatment [43-45]. The mentioned adverse effects include: burning sensation, itching of the skin and irritation at the place of application of the preparation. In 2006, the Food and Drug Administration added a warning about the possible association of tacrolimus and pimecrolimus with development of cutaneous lymphomas. On the basis of many analyzes and prospective studies, such a causative relationship has been clearly denied [46, 47]. When using $\mathrm{tCI}$, the skin's exposure to solar radiation should be limited and phototherapy should not be used in parallel. Before starting these drugs, the patient and his/her parents/guardians should be informed about correct principles of photoprotection. There are insufficient data on the safety of these drugs in pediatric patients with psoriatic erythroderma.

\section{Topical vitamin D analogues}

Topical vitamin D analogues: calcipotriol and tacalcitol, have the ability to inhibit the proliferation of keratinocytes, inhibit DNA synthesis, have an anti-angiogenic effect and enhance the terminal differentiation of keratinocytes. Due to their synergistic effect, they are often used in combination with tGCSs $[48,49]$. The use of vitamin $\mathrm{D}$ analogues in psoriasis in children is safe, as demonstrated by clinical trials. Darley et al. [49] used topical calcipotriol in 58 children aged 3-14 years (8 weeks, twice a day). Complete remission of lesions was achieved in $65 \%$ of children. Similar clinical results, also indicating good drug tolerance, were obtained by other researchers [50]. Onset of action of vitamin D analogues is observed in the $2^{\text {nd }}$ week of application, and the maximum effect - in the $6-8^{\text {th }}$ week [51]. Obtained data allow to consider vitamin $\mathrm{D}$ analogues as the first-line treatment of psoriasis in children, especially in the case of limited skin lesions [52]. Due to the risk of sadnionych przypadkach przed zastosowaniem mGKS można początkowo aplikować preparaty keratolityczne lub połączenie mGKS z kwasem salicylowym.

Leczenie mGKS należy prowadzić pod ścisłą kontrolą dermatologiczną ze względu na możliwość wystąpienia wielu działań niepożądanych, do których przede wszystkim zalicza się rozstępy, atrofię, hipertrichozę, trądzik, zapalenie mieszków włosowych, przebarwienia i odbarwienia, teleangiektazje oraz tachyfilaksję. Objawy ogólnoustrojowe (np. zahamowanie osi podwzgórzeprzysadka-nadnercza, zahamowanie wzrostu, przełom nadciśnieniowy) w zasadzie obecnie nie występują. Przy poprawnym stosowaniu leków, pod kontrolą lekarza, $\mathrm{w}$ uzupełnieniu z miejscowymi emolientami, zazwyczaj nie dochodzi do wystąpienia poważnych działań niepożądanych, nawet jeśli stosuje się leki przez długi czas. Podstawą jest odpowiednia współpraca lekarza z pacjentem i ustalenie planu leczenia. mGKS można stosować łącznie $\mathrm{z}$ innymi lekami miejscowymi, np. kalcypotriolem, oraz $\mathrm{z}$ leczeniem ogólnym, $\mathrm{w}$ tym $\mathrm{z}$ naświetlaniami skóry promieniami NB-UVB $(311 \mathrm{~nm})$ lub metodą PUVA, a także w trakcie leczenia ogólnego lekami konwencjonalnymi lub biologicznymi.

\section{Miejscowe inhibitory kalcyneuryny}

Miejscowe inhibitory kalcyneuryny (mIK), tj. takrolimus w maści i pimekrolimus w kremie, są zarejestrowane $w$ leczeniu atopowego zapalenia skóry u dzieci w wieku 2 lat i powyżej. Zgodnie z zaleceniami wielu autorów, a także doświadczeniami własnymi, rekomendujemy je jako leki pierwszego wyboru w przypadku zmian łuszczycowych zlokalizowanych na twarzy, w okolicach narządów płciowych lub okolicach wyprzeniowych $[9,28,41]$. Badań z zastosowaniem mIK u dzieci z luszczycą jest bardzo niewiele. $\mathrm{W}$ jednym $\mathrm{z}$ nich określano skuteczność takrolimusu $\mathrm{w}$ leczeniu łuszczycy na twarzy oraz okolicach wyprzeniowych (11 dzieci, wiek 6-15 lat). U 8 chorych po 30 dniach terapii uzyskano bardzo dobry efekt terapeutyczny [42]. Podobne obserwacje podawali również inni autorzy, przy czym były to analizy retrospektywne bądź opisy przypadków. Wskazywano, że efekt kliniczny widoczny jest po około 2 tygodniach leczenia [43-45]. Do wymienianych działań niepożądanych zalicza się pieczenie, świąd skóry oraz podrażnienie w miejscu aplikacji preparatu. W 2006 roku Amerykańska Agencja Żywności i Leków dodała ostrzeżenie o możliwym związku takrolimusu i pimekrolimusu z rozwojem chłoniaków skóry. Na podstawie przeprowadzonych wielu analiz oraz badań prospektywnych jednoznacznie zaprzeczono takiemu związkowi przyczynowo-skutkowemu [46, 47]. Podczas stosowania mIK należy ograniczać narażanie skóry na działanie promieniowania słonecznego oraz nie stosować równolegle fototerapii. Przed włączeniem tych leków powinno się poinformować pacjenta i jego rodziców lub 
systemic hypercalcemia, these preparations should not be used on large surfaces. It is assumed that calcipotriol can be used once a day on skin lesions not exceeding $30 \%$ of the body surface, while tacalcitol - below 15\% [26]. According to the SmPC, tacalcitol should not be used in children under 12 years of age, while calcipotriol in children over 12 years of age should be administered in the maximum weekly dose of $75 \mathrm{~g}$, while in the 6-12 age group - at the maximum weekly dose of $50 \mathrm{~g}$. Among the local adverse effects after the application of vitamin D analogues, irritation and burning sensation are often observed, therefore their use on skin lesions located on the face, genitals and in intertriginous areas should be avoided. These symptoms usually disappear with the duration of drug use and can be alleviated by simultaneous use of emollients [50, 53, 54]. Vitamin D analogues should be used with particular caution in patients with impaired calcium-phosphate metabolism and renal diseases.

\section{Combined treatment with calcipotriol/ betamethasone}

The combination of betamethasone and calcipotriol is, according to Recommendations of the Polish Dermatological Society, the treatment of choice in smooth skin psoriasis of mild intensity and recommended in the treatment of scalp psoriasis. According to the SmPC, the drug can be used in patients over 18 years of age. In 2020, results of the phase II study with calcipotriol/betamethasone foam in children with mild psoriasis $(n=106)$ aged $12-17$ were published [55]. The efficacy and safety of the preparation was assessed during the 4-week treatment (application once a day). The mean clinical improvement in the PASI index was $82 \%$, no significant deviations in the influence on the hypothalamic-pituitary-adrenal axis or on the calcium-phosphate balance were observed. Obtained results of the clinical study authorize the use of this formulation in adolescents over 12 years of age, with the principle of application to psoriatic lesions covering less than $30 \%$ of the body surface area. A similar study was conducted with an ointment formulation, the results have yet to be published [56].

\section{Tazarotene}

Tazarotene is a $3^{\text {rd }}$-generation topical retinoid approved for the treatment of plaque psoriasis in adult patients. No clinical trials have been conducted with this drug in the pediatric population, and information on its efficacy in this group of patients comes only from reports of single clinical cases, particularly pointing to its potential role in the reduction of isolated psoriatic lesions on nails [57]. In justified cases opiekunów o prawidłowych zasadach fotoprotekcji. Nie ma wystarczających danych na temat bezpieczeństwa leków tej grupy u dzieci z erytrodermią w przebiegu łuszczycy.

\section{Miejscowe analogi witaminy D}

Miejscowe analogi witaminy D: kalcypotriol i takalcytol, mają zdolność hamowania proliferacji keratynocytów, hamują syntezę DNA, mają działanie antyangiogenne oraz nasilają terminalne różnicowanie keratynocytów. Ze względu na efekt synergistyczny często są stosowane w skojarzeniu z mGKS [48, 49]. Stosowanie analogów witaminy $\mathrm{D}$ w łuszczycy $\mathrm{u}$ dzieci jest bezpieczne, na co wskazują przeprowadzone badania kliniczne. Darley i wsp. [49] stosowali miejscowo kalcypotriol u 58 dzieci w wieku 3-14 lat (8 tygodni, 2 razy dziennie). U 65\% dzieci uzyskano całkowitą remisję zmian chorobowych. Podobne wyniki kliniczne wskazujące również na dobrą tolerancję leku uzyskali inni badacze [50]. Początek działania analogów witaminy D obserwuje się w 2. tygodniu aplikacji, a efekt maksymalny - w 6.-8. tygodniu [51]. Uzyskane dane pozwalają uznać analogi witaminy D za leczenie pierwszego wyboru łuszczycy u dzieci, zwłaszcza w przypadku ograniczonych zmian skórnych [52]. Ze względu na ryzyko wystąpienia systemowej hiperkalcemii nie należy tych preparatów stosować na duże powierzchnie. Uznaje się, że kalcypotriol może być stosowany raz dziennie na zmiany skórne nieprzekraczające $30 \%$ powierzchni skóry, natomiast takalcytol - poniżej 15\% [26]. Zgodnie z charakterystykami produktów leczniczych takalcytol nie powinien być stosowany u dzieci poniżej 12. roku życia, natomiast kalcypotriol u dzieci powyżej 12 lat powinien być aplikowany w maksymalnej dawce tygodniowej $75 \mathrm{~g}$, natomiast w grupie wiekowej 6-12 lat w maksymalnej dawce tygodniowej $50 \mathrm{~g}$. Spośród miejscowych działań niepożądanych po nałożeniu analogów witaminy D obserwuje się często podrażnienie i pieczenie skóry, dlatego też należy unikać ich stosowania na zmiany skórne zlokalizowane na twarzy, narządach płciowych i w okolicach wyprzeniowych. Objawy te zazwyczaj ustępują z czasem stosowania leków i mogą być łagodzone poprzez jednoczesne stosowanie emolientów $[50,53,54]$. Analogi witaminy D szczególnie rozważnie powinny być aplikowane u pacjentów z zaburzeniami gospodarki fosforanowo-wapniowej i z chorobami nerek.

\section{Leczenie skojarzone kalcypotriol/betametazon}

Połączenie betametazonu z kalcypotriolem jest według rekomendacji Polskiego Towarzystwa Dermatologicznego leczeniem z wyboru w łuszczycy skóry gładkiej o łagodnym nasileniu oraz rekomendowane w terapii łuszczycy skóry owłosionej głowy. Zgodnie z charakterystyką produktu leczniczego preparat może być stosowany u pacjentów powyżej 18. roku życia. 
tazarotene can be used in adolescents on limited hyperkeratotic changes. However, its teratogenic potential should be borne in mind and appropriate safety measures should be taken. Despite registration, the drug has not been available in Poland for a long time.

\section{CONFLICT OF INTEREST}

The authors declare no conflict of interest.
W 2020 roku opublikowane zostały wyniki badania II fazy z zastosowaniem preparatu kalcypotriol/betametazon $\mathrm{w}$ pianie $\mathrm{u}$ dzieci $(n=106) \mathrm{w}$ wieku $12-17$ lat z łagodną łuszczycą [55]. Oceniano skuteczność i bezpieczeństwo preparatu w 4-tygodniowej terapii (aplikacja raz dziennie). Średnia poprawa kliniczna wskaźnika PASI wynosiła $82 \%$, nie stwierdzono istotnych odchyleń w zakresie wpływu na oś podwzgórzeprzysadka-nadnercze i na gospodarkę fosforanowo-wapniową. Wyniki badania klinicznego upoważniają do stosowania tej formulacji u nastolatków powyżej 12. roku życia, z zachowaniem zasady aplikacji na zmiany łuszczycowe niezajmujące powierzchni skóry powyżej $30 \%$. Podobne badanie przeprowadzono $\mathrm{z}$ formulacją w maści, wyniki nie zostały jeszcze opublikowane [56].

\section{Tazaroten}

Tazaroten jest miejscowym retinoidem trzeciej generacji, zarejestrowanym do leczenia łuszczycy plackowatej u pacjentów dorosłych. Nie przeprowadzano badań klinicznych z zastosowaniem tego leku w populacji dziecięcej, a informacje dotyczące jego skuteczności w tej grupie chorych pochodzą jedynie z opisów pojedynczych przypadków klinicznych, wskazujących szczególnie na jego potencjalną rolę w redukcji izolowanych zmian łuszczycowych na paznokciach [57]. Tazaroten można w uzasadnionych przypadkach stosować u młodzieży na ograniczone zmiany hiperkeratotyczne. Należy jednak pamiętać o jego potencjale teratogennym i zastosować odpowiednie środki bezpieczeństwa. Pomimo zarejestrowania lek od dłuższego czasu nie jest dostępny w Polsce.

\section{KONFLIKT INTERESÓW}

Autorzy nie zgłaszają konfliktu interesów.

\section{References}

\section{Piśmiennictwo}

1. Reich A., Adamski Z., Chodorowska G., Kaszuba A., Krasowska D., Lesiak A., et al.: Psoriasis. Diagnostic and therapeutic recommendations of the Polish Dermatological Society. Part 1. Dermatol Rev 2020, 107, 92-108.

2. Piekarska-Myślińska D., Pietrzak A., Myśliński W., Pietrzak D., Borysowicz M., Socha M., et al.: Childhood psoriasis. Dermatol Rev 2017, 104, 363-376.

3. Burden-Teh E., Thomas K.S., Ratib S., Grindlay D., Adaji E., Murphy R.: The epidemiology of childhood psoriasis: a scoping review. Br J Dermatol 2016, 174, 1242-1257.

4. Augustin M., Glaeske G., Radtke M.A., Christophers E., Reich K., Schafer I.: Epidemiology and comorbidity of psoriasis in children. Br J Dermatol 2010, 162, 633-636.

5. Mahe E.: Child psoriasis. Eur J Dermatol 2016, 26, 537-548.

6. Murphy M., Kerr P., Grant-Kels J.M.: The histopathologic spectrum of psoriasis. Clin Dermatol 2007, 25, 524-528.

7. Salek M.S., Jung S., Brincat-Ruffini L.A., MacFarlane L., Lewis-Jones M.S., Basra M.K., et al.: Clinical experience and psychometric properties of the Children's Dermatology Life Quality Index (CDLQI), 1995-2012. Br J Dermatol 2013, 169, 734-759.

8. Holme S.A., Man I., Sharpe J.L., Dykes P.J., Lewis-Jones M.S., Finlay A.Y.: The Children's Dermatology Life Quality Index: validation of the cartoon version. Br J Dermatol 2003, 148, 285-290. 
9. Menter A., Cordoro K.M., Davis D.M.R., Kroshinsky D., Paller A.S., Armstrong A.W., et al.: Joint American Academy of Dermatology - National Psoriasis Foundation guidelines of care for the management and treatment of psoriasis in pediatric patients. J Am Acad Dermatol 2020, 82, 161-201.

10. Smolewska E., Żuber Z.: Current goals of opportunities and prospects for the treatment of juvenile idiopathic arthritis in Poland and in the world. Forum Reumatol 2016, 2, 14-20.

11. Ogdie A., Weiss P.: The epidemiology of psoriatic arthritis. Rheum Dis Clin North Am 2015, 41, 545-568.

12. Osier E., Wang A.S., Tollefson M.M., Cordoro K.M., Daniels S.R., Eichenfield A., et al.: Pediatric psoriasis comorbidity screening guidelines. JAMA Dermatol 2017, 153, 698-704.

13. Stoll M.L., Punaro M.: Psoriatic juvenile idiopathic arthritis: a tale of two subgroups. Curr Opin Rheumatol 2011, $23,437-443$.

14. Lewkowicz D., Gottlieb A.B.: Pediatric psoriasis and psoriatic arthritis. Dermatol Ther 2004, 17, 364-375.

15. Petty R.E., Southwood T.R., Manners P., Baum J., Glass D.N., Goldenberg J., et al.: International League of Associations for Rheumatology classification of juvenile idiopathic arthritis: second revision, Edmonton, 2001. J Rheumatol 2004, $31,390-392$.

16. Goldminz A.M., Buzney C.D., Kim N., Au S.C., Levine D.E., Wang A.C., et al.: Prevalence of the metabolic syndrome in children with psoriatic disease. Pediatr Dermatol 2013, 30, 700-705.

17. Boccardi D., Menni S., La Vecchia C., Nobile M., Decarli A., Volpi G., et al.: Overweight and childhood psoriasis. Br J Dermatol 2009, 161, 484-486.

18. Augustin M., Radtke M.A., Glaeske G., Reich K., Christophers E., Schaefer I., et al.: Epidemiology and comorbidity in children with psoriasis and atopic eczema. Dermatology 2015, 231, 35-40.

19. Kwa L., Kwa M.C., Silverberg J.I.: Cardiovascular comorbidities of pediatric psoriasis among hospitalized children in the United States. J Am Acad Dermatol 2017, 77, 1023-1029.

20. Boehncke W.H., Boehncke S., Tobin A.M., Kirby B.: The 'psoriatic march': a concept of how severe psoriasis may drive cardiovascular comorbidity. Exp Dermatol 2011, 20, 303-307.

21. Gottlieb A.B., Chao C., Dann F.: Psoriasis comorbidities. J Dermatolog Treat 2008, 19, 5-21.

22. Todberg T., Egeberg A., Jensen P., Gislason G., Skov L.: Psychiatric comorbidities in children and adolescents with psoriasis: a population-based cohort study. Br J Dermatol 2017, 177, 551-553.

23. Bilgic A., Bilgic O., Akis H.K., Eskioglu F., Kilic E.Z.: Psychiatric symptoms and health-related quality of life in children and adolescents with psoriasis. Pediatr Dermatol 2010, 27, 614-617.

24. Menter A., Korman N.J., Elmets C.A., Feldman S.R., Gelfand J.M., Gordon K.B., et al.: Guidelines of care for the management of psoriasis and psoriatic arthritis. Section 3. Guidelines of care for the management and treatment of psoriasis with topical therapies. J Am Acad Dermatol 2009, 60, 643-59.

25. Madan R.K., Levitt J.: A review of toxicity from topical salicylic acid preparations. J Am Acad Dermatol $2014,70,788-792$.

26. Eisert L., Augustin M., Bach S., Dittmann M., Eiler R., Fölster-Holst R., et al.: S2k guidelines for the treatment of psoriasis in children and adolescents. Short version part 1. J Dtsch Dermatol Ges 2019, 17, 856-870.

27. Mrowietz U., Jessat H., Schwarz A., Schwarz T.: Anthralin (dithranol) in vitro inhibits human monocytes to secrete IL-6, IL-8 and TNF-alpha, but not IL-1. Br J Dermatol 1997, 136, 542-547.

28. de Jager M.E., van de Kerkhof P.C., de Jong E.M., Seyger M.M.: Dithranol therapy in childhood psoriasis: unjustifiably on the verge of falling into oblivion. Dermatology 2010, 220, 329-332.

29. Zvulunov A., Anisfeld A., Metzker A.: Efficacy of short-contact therapy with dithranol in childhood psoriasis. Int J Dermatol 1994, 33, 808-810.

30. Oostveen A.M., Beulens C.A., van de Kerkhof P.C., de Jong E.M., Seyger M.M.: The effectiveness and safety of short-contact dithranol therapy in paediatric psoriasis: a prospective comparison of regular day care and day care with telemedicine. Br J Dermatol 2014, 170, 454-457.

31. Guerrier C.J., Porter D.I.: An open assessment of $0.1 \%$ dithranol in a $17 \%$ urea base ('Psoradrate' $0.1 \%$ ) in the treatment of psoriasis of children. Curr Med Res Opin 1983, 8, 446-450.

32. Kortuem K.R., Davis M.D., Witman P.M., McEvoy M.T., Farmer S.A.: Results of Goeckerman treatment for psoriasis in children: a 21-year retrospective review. Pediatr Dermatol 2010, 27, 518-524.

33. Menter M.A., Whiting D.A., McWilliams J.: Resistant childhood psoriasis: an analysis of patients seen in a day-care center. Pediatr Dermatol 1984, 2, 8-12.

34. Borska L., Andrys C., Krejsek J., Hamakova K., Kremlacek J., Ettler K., et al.: Genotoxic hazard and cellular stress in pediatric patients treated for psoriasis with the Goeckerman regimen. Pediatr Dermatol 2009, 26, 23-27.

35. Borska L., Smejkalova J., Cerna M., Hamakova K., Kucera I., Kremlacek J., et al.: Urinary mutagenicity and genotoxic risk in children with psoriasis after therapeutic exposure to polycyclic aromatic hydrocarbons and ultraviolet radiation. Mutat Res 2010, 696, 144-147.

36. Borska L., Fiala Z., Krejsek J., Andrys C., Vokurkova D., Hamakova K., et al.: Immunologic changes in TNF-alpha, sE-selectin, sP-selectin, sICAM-1, and IL-8 in pediatric patients treated for psoriasis with the Goeckerman regimen. Pediatr Dermatol 2007, 24, 607-612.

37. Borska L., Andrys C., Krejsek J., Palicka V., Chmelarova M., Hamakova K., et al.: Oxidative damage to nucleic acids and benzo(a)pyrene-7,8-diol-9,10-epoxide-DNA adducts and chromosomal aberration in children with psoriasis repeatedly exposed to crude coal tar ointment and UV radiation. Oxid Med Cell Longev 2014, 2014, 302528.

38. Frangos J.E., Kimball A.B.: Clobetasol propionate emollient formulation foam in the treatment of corticosteroidresponsive dermatoses. Expert Opin Pharmacother 2008, 9, 2001-2007.

39. Herz G., Blum G., Yawalkar S.: Halobetasol propionate cream by day and halobetasol propionate ointment at night for the treatment of pediatric patients with chronic, localized plaque psoriasis and atopic dermatitis. J Am Acad Dermatol 1991, 25, 1166-1169.

40. Tollefson M.M.: Diagnosis and management of psoriasis in children. Pediatr Clin North Am 2014, 61, $261-277$.

41. Kravvas G., Gholam K.: Use of topical therapies for pediatric psoriasis: a systematic review. Pediatr Dermatol 2018, 35, 296302. 
42. Brune A., Miller D.W., Lin P., Cotrim-Russi D., Paller A.S.: Tacrolimus ointment is effective for psoriasis on the face and intertriginous areas in pediatric patients. Pediatr Dermatol 2007, 24, 76-80.

43. Steele J.A., Choi C., Kwong P.C.: Topical tacrolimus in the treatment of inverse psoriasis in children. J Am Acad Dermatol 2005, 53, 713-716.

44. Amichai B.: Psoriasis of the glans penis in a child successfully treated with Elidel (pimecrolimus) cream. J Eur Acad Dermatol Venereol 2004, 18, 742-743.

45. Mansouri P., Farshi S.: Pimecrolimus 1 percent cream in the treatment of psoriasis in a child. Dermatol Online J $2006,12,7$.

46. Siegfried E.C., Jaworski J.C., Kaiser J.D., Hebert A.A.: Systematic review of published trials: long-term safety of topical corticosteroids and topical calcineurin inhibitors in pediatric patients with atopic dermatitis. BMC Pediatr 2016, 16, 75.

47. Paller A.S., Fölster-Holst R., Chen S.C., Diepgen T.L., Elmets C., Margolis D.J., et al.: No evidence of increased cancer incidence in children using topical tacrolimus for atopic dermatitis. J Am Acad Dermatol 2020, 83, 375-381.

48. Lovato P., Norsgaard H., Tokura Y., Ropke M.A.: Calcipotriol and betamethasone dipropionate exert additive inhibitory effects on the cytokine expression of inflammatory dendritic cellTh17 cell axis in psoriasis. J Dermatol Sci 2016, 81, 153-164.

49. Darley C.R., Cunliffe W.J., Green C.M., Hutchinson P.E., Klaber M.R., Downes N.: Safety and efficacy of calcipotriol ointment (Dovonex) in treating children with psoriasis vulgaris. Br J Dermatol 1996, 135, 390-393.

50. Oranje A.P., Marcoux D., Svensson A., Prendiville J., Krafchik B., Toole J., et al.: Topical calcipotriol in childhood psoriasis J Am Acad Dermatol 1997, 36, 203-208.

51. Sticherling M., Augustin M., Boehncke W.H., Christophers E., Domm S., Gollnick H., et al.: Therapy of psoriasis in childhood and adolescence - a German expert consensus. J Dtsch Dermatol Ges 2011, 9, 815-823.

52. de Jager M.E., de Jong E.M., van de Kerkhof P.C., Seyger M.M.: Efficacy and safety of treatments for childhood psoriasis: a systematic literature review. J Am Acad Dermatol 2010, 62, 1013-1030.

53. Patrizi A., Neri I., Rizzoli L., Varotti C.: Topical calcipotriol in childhood psoriasis. Acta Derm Venereol 1999, 79, 477.

54. Park S.B., Suh D.H., Youn J.I.: A pilot study to assess the safety and efficacy of topical calcipotriol treatment in childhood psoriasis. Pediatr Dermatol 1999, 16, 321-325.

55. Seyger M., Abramovits W., Liljedahl M., Hoejen M.N., Teng J.: Safety and efficacy of fixed-dose combination calcipotriol $(50 \mu \mathrm{g} / \mathrm{g})$ and betamethasone dipropionate $(0.5 \mathrm{mg} / \mathrm{g})$ cutaneous foam in adolescent patients (aged 12 to <17 years) with plaque psoriasis: results of a phase II, open-label trial. J Eur Acad Dermatol Venereol 2020, 34, $2026-2034$.

56. https:/ / clinicaltrials.gov/ct2/show/results/NCT00817219?cond=Psoriasis+Vulgaris\&age=0\&draw=4\&rank

57. Diluvio L., Campione E., Paterno E.J., Mordenti C., El Hachem M., Chimenti S.: Childhood nail psoriasis: a useful treatment with tazarotene $0.05 \%$. Pediatr Dermatol 2007, 24, 332-333.

Received: 25.08 .2021

Accepted: 30.08 .2021

Otrzymano: $25.08 .2021 \mathrm{r}$

Zaakceptowano: $30.08 .2021 \mathrm{r}$.

How to cite this article

Narbutt J., Reich A., Adamski Z., Chodorowska G., Kaszuba A., Krasowska D., Lesiak A., Maj J., Osmola-Mańkowska A.J., Owczarczyk-Saczonek A.B., Owczarek W., Placek W.J., Rudnicka L., Szepietowski J.: Psoriasis in children. Diagnostic and therapeutic recommendations of the Polish Dermatological Society. Part 1. Dermatol Rev/Przegl Dermatol 2021, 108, $239-257$. DOI: https://doi.org/10.5114/dr.2021.110913. 